\title{
Radar-Observed Characteristics of Precipitation in the Tropical High Andes of Southern Peru and Bolivia
}

\author{
JASOn L. Endries, ${ }^{\mathrm{a}}$ L. BAKer Perry, ${ }^{\mathrm{a}}$ SANDra E. Yuter, ${ }^{\mathrm{b}}$ ANTON SeImON, ${ }^{\mathrm{a}, \mathrm{c}}$ \\ Marcos Andrade-Flores, ${ }^{\mathrm{d}}$ Ronald WinKelmann, ${ }^{\mathrm{d}}$ Nelson QuisPe, ${ }^{\mathrm{e}}$ MAXWEll Rado, ${ }^{\mathrm{f}}$ \\ Nilton Montoya, ${ }^{\mathrm{f}}$ Fernando Velarde, ${ }^{\mathrm{d}}$ AND SANDro ARIAS ${ }^{\mathrm{e}}$ \\ ${ }^{a}$ Department of Geography and Planning, Appalachian State University, Boone, North Carolina \\ ${ }^{\mathrm{b}}$ Department of Marine, Earth, and Atmospheric Sciences, North Carolina State University at Raleigh, Raleigh, North Carolina \\ ${ }^{\mathrm{c}}$ Climate Change Institute, University of Maine, Orono, Maine \\ d Laboratorio de Física de la Atmosfera, Instituto de Investigaciones Físicas, Universidad Mayor de San Andrés, La Paz, Bolivia

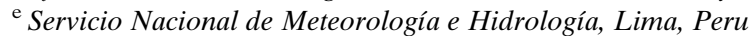 \\ ${ }^{\mathrm{f}}$ Universidad Nacional de San Antonio de Abád de Cusco, Cusco, Peru
}

(Manuscript received 5 September 2017, in final form 23 April 2018)

\begin{abstract}
This study used the first detailed radar measurements of the vertical structure of precipitation obtained in the central Andes of southern Peru and Bolivia to investigate the diurnal cycle and vertical structure of precipitation and melting-layer heights in the tropical Andes. Vertically pointing 24.1-GHz Micro Rain Radars in Cusco, Peru (3350 m MSL, August 2014-February 2015), and La Paz, Bolivia (3440 m MSL, October 2015-February 2017), provided continuous 1-min profiles of reflectivity and Doppler velocity. The time-height data enabled the determination of precipitation timing, melting-layer heights, and the identification of convective and stratiform precipitation features. Rawinsonde data, hourly observations of meteorological variables, and satellite and reanalysis data provided additional insight into the characteristics of these precipitation events. The radar data revealed a diurnal cycle with frequent precipitation and higher rain rates in the afternoon and overnight. Short periods with strong convective cells occurred in several storms. Longer-duration events with stratiform precipitation structures were more common at night than in the afternoon. Backward air trajectories confirmed previous work indicating an Amazon basin origin of storm moisture. For the entire dataset, median melting-layer heights were above the altitude of nearby glacier termini approximately $17 \%$ of the time in Cusco and $30 \%$ of the time in La Paz, indicating that some precipitation was falling as rain rather than snow on nearby glacier surfaces. During the 2015-16 El Niño, almost half of storms in La Paz had melting layers above $5000 \mathrm{~m}$ MSL.
\end{abstract}

\section{Introduction}

The glaciers of the tropical Andes of southern Peru and western Bolivia have experienced substantial impacts due to climate change, with extensive retreat and negative mass balance since 1980 including the disappearance of many small glaciers (Francou et al. 2003; Rabatel et al. 2013; Salzmann et al. 2013; Hanshaw and Bookhagen 2014). Increasing atmospheric temperatures, a rising melting-layer height (i.e., the altitude of the $0^{\circ} \mathrm{C}$ level), and the possibility of more frequent El Niño events (Cai et al. 2014; Christensen et al. 2013) are threatening the disappearance of an important freshwater source and thousands of years of glacial paleoclimate

Corresponding author: Jason Endries, endriesjl@appstate.edu records (Rabatel et al. 2013; Salzmann et al. 2013; Schauwecker et al. 2017). Sparse information on the precipitation processes and patterns that control the behavior of these glaciers limits the ability both to adequately prepare for future climate change and to reconstruct historical climates from ice cores obtained from this region.

More than $90 \%$ of all tropical glaciers (latitudes less than $\sim 20^{\circ}$ ) worldwide are found in Peru and Bolivia (Kaser 1999), a large portion of which exist between $12^{\circ}$ and $16^{\circ} \mathrm{S}$ in southern Peru and western Bolivia (Fig. 1). The equilibrium line altitude (ELA) on these glaciers, the altitude where mass is neither gained nor lost, has risen to as high as $5400 \mathrm{~m}$ above mean sea level (m MSL; all altitudes hereinafter are MSL, except where otherwise noted) (Rabatel et al. 2013; Hanshaw and 


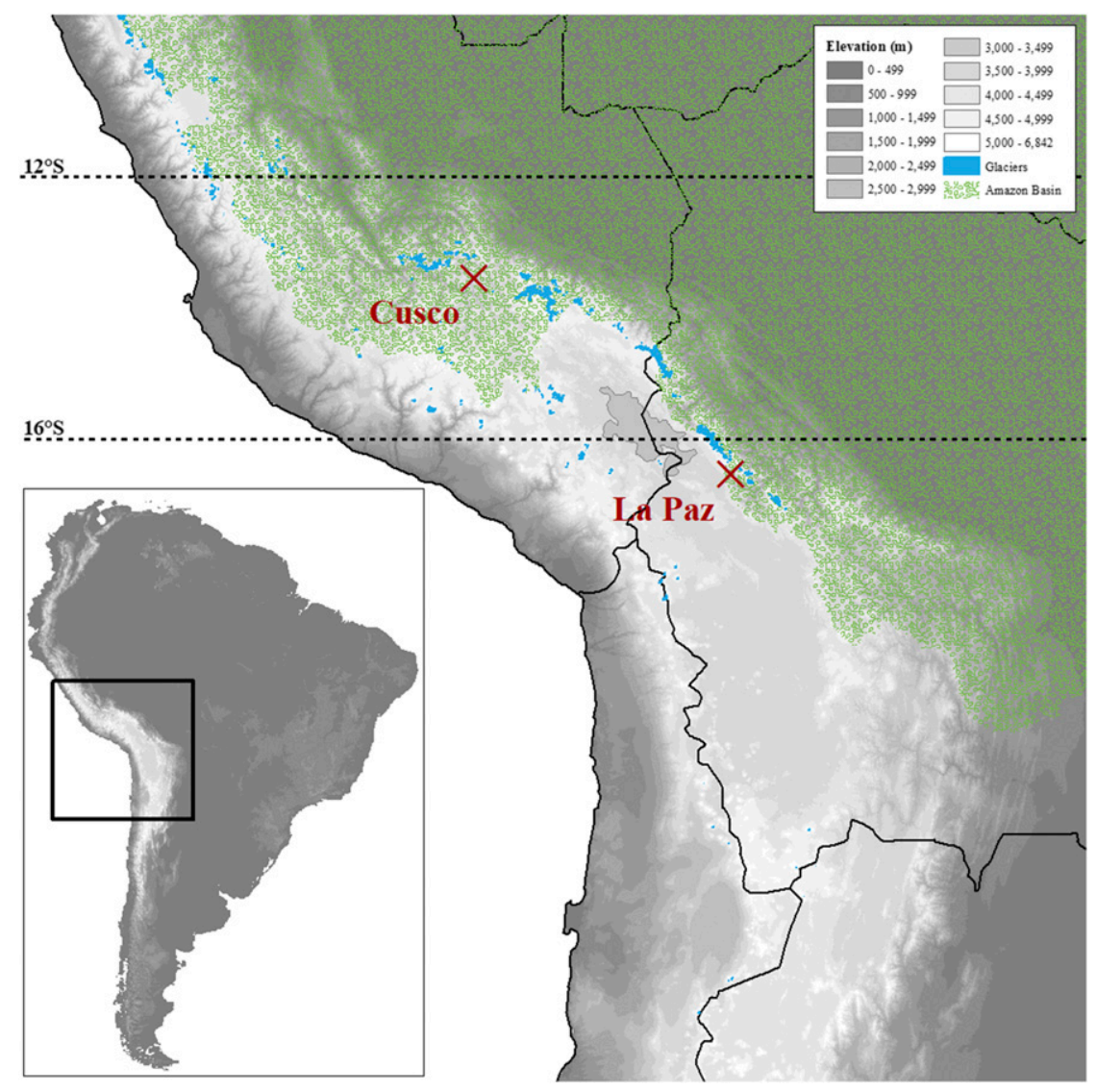

FIG. 1. Study area showing the central Andes, including Cusco and La Paz (locations of the MRR deployments), surrounding glaciers, and the Amazon basin.

Bookhagen 2014). The high ELA has contributed to decreasing glacial area and negative mass balance. Precipitation intensity, duration, and the melting-layer height play key roles in the determination of the ELA by influencing glacial surface albedo, an important control of ablation (Francou et al. 2003; Salzmann et al. 2013; Hanshaw and Bookhagen 2014). Fresh snow will sustain high albedo, whereas rain can promote melting, significantly reduce albedo, and expose older, darker glacier surfaces.

There is a limited understanding of the mechanisms that control vertical precipitation structure, as well as the character and diurnal cycle of precipitation events in the tropical Andes (Francou et al. 2003; Perry et al. 2014). Rising melting-layer heights are a major contributing factor to the increased ablation of snow and ice, and in some cases the complete disappearance of glaciers in recent decades (Francou et al. 2003; Salzmann et al. 2013). Precipitation diurnal cycle and character, referring to longduration weaker stratiform precipitation or short and more intense convective precipitation, also play important roles in determining precipitation types and accumulation that a single event delivers to the surface. Improved insight into the spatial and temporal complexities of the melting-layer height and precipitation duration and intensity can help the people of Peru and Bolivia to manage their water resources in a warming climate and help paleoscientists interpret the ice-core records of past climates.

Using observational data from 536 precipitation events captured by a high-elevation vertically pointing radar during deployments at two locations, this study addresses two questions: 1) How do the diurnal cycles and vertical structures of precipitation vary at Cusco, Peru, and La Paz, Bolivia? 2) What are the associated spatial and temporal distributions of melting-layer heights? The findings developed from the analysis help to provide insight into conceptual models of precipitation delivery in the region and may contribute to understanding precipitation-glacier interactions in a changing climate.

Section 2 presents a synthesis of the current understanding of precipitation climatology in the tropical Andes, as well as past applications of using vertically pointing radar observations to detect the melting layer 
and the character of precipitation. Section 3 provides a summary of the results and an analysis of four case studies that are characteristic of precipitation events observed in the dataset. In section 4, the results and their implications for our understanding of precipitation patterns in the tropical high Andes are discussed. Finally, section 5 summarizes the findings and presents some applications of the work.

\section{Background}

\section{a. Precipitation climatology in the tropical Andes}

The meteorology of the Andean regions of Peru and Bolivia is characterized by a closed upper-tropospheric counterclockwise circulation centered over Bolivia during austral summer called the Bolivian high (Vuille 1999). A distinct wet season occurs during austral summer from December to February as the Bolivian high is displaced southward (poleward) and intensifies (Vuille 1999). Upper-level easterly winds ensue associated with a poleward expansion of the belt of equatorial easterlies (Garreaud et al. 2003). These winds transport abundant lower-tropospheric Amazonian moisture over the South American Altiplano during the wet season and periods of anomalous easterly zonal winds (Garreaud et al. 2003). Westerly winds dominate from May to October during the dry season as the Bolivian high weakens (Garreaud et al. 2003).

On seasonal-to-annual time scales, precipitation in the tropical high Andes is also regulated by teleconnections to large-scale phenomena such as El NiñoSouthern Oscillation (ENSO). Vuille (1999) found that during El Niño austral summers, westerlies and northerlies increase in the middle and upper troposphere, specific humidity is reduced, and the troposphere is anomalously warm. Stronger westerlies may inhibit the easterly penetration of moist air from interior South America into the Altiplano (Vuille 1999). During El Niño, the Bolivian high is weakened and displaced to the north, and precipitation in the Altiplano is reduced. Vuille (1999) found that conditions are overall opposite during La Niña austral summers. However, since the topography of the Andes creates complex spatial patterns of daily convective activity (Giovannettone and Barros 2009), the impact of ENSO varies depending on the locality. El Niño conditions resulted in less precipitation and higher surface temperatures in the region of the Chacaltaya and Zongo glaciers in the Cordillera Real, Bolivia (Wagnon et al. 2001; Francou et al. 2003). On the other hand, in Cusco and the Cordillera Vilcanota in south-central Peru, El Niño led to positive precipitation anomalies while La Niña produced negative anomalies (Perry et al. 2014).
Moisture advection for most precipitation events observed in the central Andes originates from Amazonian lowlands. Near the Cordillera Vilcanota $\left(\sim 14^{\circ} \mathrm{S}\right)$, a heavily glacierized range in southern Peru, $95 \%$ of the events during the hydrological year at Cusco occur with 72-h moisture trajectories inflowing from the Amazon basin (Perry et al. 2014). Data from meteorological stations reveal that this influx of moisture occurs across the entire Altiplano and affects the meteorology of the whole region as a result (Garreaud 2000). Precipitation typically occurs in alternating periods of wet and dry episodes, each of about 1-week duration, corresponding to fluctuations in the zonal flow (Garreaud et al. 2003; Falvey and Garreaud 2005). Moist periods frequently result in active convection in the Altiplano (Garreaud et al. 2003).

At the mesoscale, several studies indicate a bimodal daily pattern of precipitation occurrence across the central and northern Andes, with peaks in the overnight hours and afternoon (Bendix et al. 2006, 2009; Romatschke and Houze 2013; Mohr et al. 2014; Perry et al. 2014). The afternoon maximum results from convective activity following surface heating (Bendix et al. 2006, 2009; Krois et al. 2013; Perry et al. 2014). During the late night to early morning period, Tropical Rainfall Measuring Mission (TRMM; Kummerow et al. 1998) satellite data show a peak in the occurrence of large-extent precipitation echoes across the Amazon basin (Romatschke and Houze 2013). Romatschke and Houze (2010) attribute the detection of these broad echoes, which typically occur in the hours after wide convective cores develop, to be evidence that MCSs are the source of the nighttime precipitation in the Amazon. The nighttime maximum detected in the Andes may be tied to these convective complexes through processes such as propagation on upper-level easterlies, and the seeder-feeder mechanism initiated by overspreading precipitating cirrus clouds from Amazonian convection (Bendix et al. 2009; Perry et al. 2014).

\section{b. Precipitation signatures in Micro Rain Radar data}

The Micro Rain Radar (MRR) is a frequencymodulated continuous-wave (FMCW) Doppler radar with a $2^{\circ}$ beamwidth offset feed antenna (Peters et al. 2005). The radar reflectivity, average Doppler velocity, and spectral width are computed from the measured Doppler velocity spectra of the targets within each resolution volume (range gate in the vertical, beamwidth in horizontal area). Unlike radars using pulsed mode where the distance to the target is based on the elapsed time between the transmission of a pulse and the reception of the echo, in FMCW radars the frequency shift between the echo and the transmitted signal is used to 
TABLE 1. Summary of data sources.

\begin{tabular}{|c|c|c|c|c|}
\hline Source and location & Variable & Temporal scale & Period & Elev $(\mathrm{m})$ \\
\hline MRR, Cusco & $\begin{array}{l}\text { Radar reflectivity, echo-top height, } \\
\text { and melting-layer height }\end{array}$ & $1 \mathrm{~min}$ & $2014-15$ & 3350 \\
\hline MRR, La Paz & $\begin{array}{l}\text { Radar reflectivity, echo-top height, } \\
\text { and melting-layer height }\end{array}$ & $1 \mathrm{~min}$ & $2015-16$ & 3440 \\
\hline SPZO METARs, Cusco & Temperature and precipitation & $1 \mathrm{~h}$ & $2014-15$ & 3248 \\
\hline SLLP METARs, El Alto, Bolivia & Temperature and precipitation & $1 \mathrm{~h}$ & $2015-16$ & 4062 \\
\hline $\begin{array}{l}\text { Meteorological Station, } \\
\text { Cota Cota, La Paz }\end{array}$ & Temperature and precipitation & $1 \mathrm{~h}$ & $2015-16$ & 3440 \\
\hline Rawinsonde, Cota Cota & Temperature & - & 2016,2017 & - \\
\hline ERA-Interim, ECMWF & Upper-level winds & $6 \mathrm{~h}$ & $2014-16$ & - \\
\hline GDAS $0.5^{\circ}$, NOAA & Backward air trajectories & $1 \mathrm{~h}$ & $2014-15$ & - \\
\hline
\end{tabular}

determine the range to the target (Peters et al. 2005; METEK 2009, p. 5).

Vertically pointing MRRs are useful for determining the vertical structure of precipitation events (Waldvogel 1974; White et al. 2002). Stratiform precipitation has a layered appearance, with a relatively narrow distribution of reflectivity values at each altitude and vertical velocities generally $<1 \mathrm{~ms}^{-1}$, while convective precipitation has a much broader distribution of reflectivity and vertical velocities that can exceed $10 \mathrm{~m} \mathrm{~s}^{-1}$ (Houze 1997). In the Andes, very few studies have utilized vertically pointing radar data to analyze precipitation structure. One such study, by Bendix et al. (2006), used an MRR deployed in southern Ecuador to demonstrate that precipitation character in the region can be inferred using rain rates. Most of the events they observed were stratiform in character with rain rates less than $2 \mathrm{~mm} \mathrm{~h}^{-1}$, although the authors noted the importance of embedded convective precipitation with rain rates greater than $10 \mathrm{~mm} \mathrm{~h}^{-1}$ as an important feature of precipitation in the Andes of southern Ecuador (Bendix et al. 2006).

The melting-layer height has been identified using vertically pointing radars in a variety of studies including White et al. (2002), Lundquist et al. (2008), Das and Maitra (2011), Minder and Kingsmill (2013), and most recently Massmann et al. (2017). Synonymous with the bight band, the melting layer is the level at which frozen hydrometeors begin to melt after falling through the $0^{\circ} \mathrm{C}$ isotherm into above-freezing temperatures. Generally, the top of the bright band provides an accurate estimate of the level of the $0^{\circ} \mathrm{C}$ isotherm and thus the top of the melting layer, as rain becomes the dominant precipitation type by the time the ambient temperature reaches $0.5^{\circ} \mathrm{C}$ (Yuter et al. 2006). This is consistent with observations in the Bolivian Andes, where more than half of the snow was melted across all precipitation samples once the air temperature rose above $0.5^{\circ} \mathrm{C}$ (L'hôte et al. 2005).
Das and Maitra (2011) identified the top of the melting layer as the altitude where the maximum negative gradient in rain rate occurred. Mean monthly data from these values, when compared with mean monthly vertical temperature profiles of rawinsonde data, proved to be accurate within $1000 \mathrm{~m}$. The methods outlined by White et al. (2002) derived the elevation of the bright band using Doppler vertical velocity and range-corrected signal-to-noise ratio. Moving up within the profile, the altitude where velocities began to decrease with height concurrently with increasing reflectivities indicated the location of the brightband peak. These methods were utilized by both Minder and Kingsmill (2013) and Lundquist et al. (2008). Used in conjunction with rawinsonde and other meteorological data, Lundquist et al. (2008) evaluated the efficacy of remotely sensed brightband levels at estimating the actual snow line on the windward mountain slopes in the Sierra Nevada. Even though the brightband heights were detected up to $300 \mathrm{~km}$ away from the mountain, they coincided well with the altitude at which the melting-layer height intersected the elevated terrain surface. Along the southern Chilean coast, Massmann et al. (2017) used two 24-GHz MRRs to observe brightband signatures in $50 \%$ of storms occurring between 22 May and 14 August 2015.

\section{Data and methods}

A wide variety of data from across the study area of southern Peru and western Bolivia was utilized for this work (Table 1). From September 2014 to February 2015, a vertically pointing 24.1-GHz MRR (LöfflerMang et al. 1999; Peters et al. 2002) collected data every minute for 169 days in Cusco $\left(13.55^{\circ} \mathrm{S}, 71.98^{\circ} \mathrm{W} ; 3350 \mathrm{~m}\right)$. The MRR was moved to $\mathrm{La} \mathrm{Paz}\left(16.54^{\circ} \mathrm{S}, 68.07^{\circ} \mathrm{W}\right.$; $3440 \mathrm{~m}$ ), where data were collected for 513 days, from October 2015 to February 2017. Range gates were spaced at $150-\mathrm{m}$ intervals at both locations. The MRR 
data were continuous over the deployed periods and therefore sampled both the wet and dry seasons. To remove noise and improve data quality and sensitivity for snow observations, these data were postprocessed using the technique outlined by Maahn and Kollias (2012).

If the vertical spatial resolution of MRR data is sufficient, the melting-layer height will appear in the vertical reflectivity profile of stratiform precipitation as a bright band, a layer of increased reflectivity followed by an increase in Doppler velocity (Houze 1997). As a snow crystal falls through the atmosphere from below to above-freezing conditions, the snowflake begins to melt. This increases the radar-detected reflectivity due to the higher dielectric constant of water than of ice. Once melting is complete, the resulting raindrop often has a smaller diameter than the originating snowflake and will also have a higher terminal fall speed.

Using these principles, highlighted by Austin and Bernis (1950), we developed an algorithm to identify the top of the melting layer as the most negative gradient in reflectivity in the profile and the bottom of the melting layer as the most negative gradient in Doppler velocity. This is similar to the algorithm outlined by White et al. (2002). However, this study uses reflectivities and velocities separately to derive the top and bottom of the melting layer instead of using a combination of the variables to derive the brightband peak. This permitted the calculation of the melting-layer thickness throughout the storm. The melting-layer height for this study was computed every minute as the bottom of the melting layer during that minute plus the average melting-layer thickness (top minus bottom) during the respective hour of the storm. The derived melting-layer height was discarded if the algorithm produced values that were 1) outside of one standard deviation of the mean of the hour in which it lies; 2) above $6000 \mathrm{~m}$ in altitude, which is considered implausible under current tropospheric conditions; or 3) existing during virga, defined as occurring when no precipitation is detected below $4000 \mathrm{~m}$. The final quality-controlled dataset is composed of the median hourly melting-layer height derived from these 1-min-derived values.

An additional dataset was developed to describe the timing and duration of precipitation events at each location. Event durations were defined as the length that echoes were detected in the range gate $450 \mathrm{~m}$ above the location of the MRR ( $3350 \mathrm{~m}$ in Cusco, $3440 \mathrm{~m}$ in La Paz). We used $450 \mathrm{~m}$ above the Micro Rain Radar instrument since the Maahn and Kollias (2012) postprocessing removes the lowest two gates. A new event was defined after $3 \mathrm{~h}$ passed with no echoes in this gate. We used the resulting data in tandem with the melting-layer heights to examine the vertical structure and duration of the

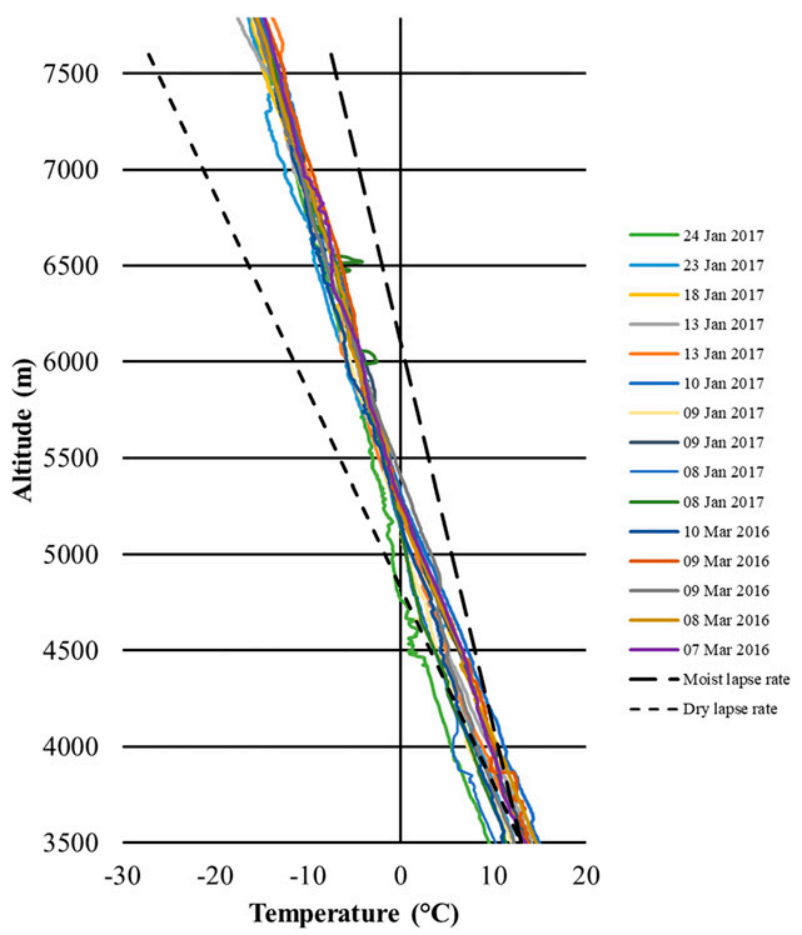

FIG. 2. Vertical temperature profiles during precipitation events recorded by rawinsonde launches in March 2016 (5 profiles) and January 2017 (10 profiles) at the site of the La Paz MRR. Representative moist- and dry-adiabatic lapse rates are indicated by the long- and short-dashed lines, respectively.

precipitation, and for a qualitative analysis of the stratiform or convective precipitation character of the events. Long-duration events with horizontally layered reflectivity values and the presence of a melting layer implied stratiform precipitation. Short-duration events with vertically oriented intense reflectivity and strong vertical motions implied convective precipitation (Houze 1997).

Surface METAR observations from the Cusco International Airport (SPZO) and El Alto International Airport (SLLP), as well as data from a meteorological station collocated with the MRR in Cota Cota, La Paz, were assembled for the MRR observation periods at each location. These helped provide a context for the conditions under which storms occurred, and a reference for the intensity of the storms using hourly rain rate. To verify the melting-layer height values and confirm a monotonically decreasing atmospheric profile (no inversions), vertical profiles of temperature were collected from 5 rawinsonde launches in early March 2016 and 10 launches in early January 2017 from the La Paz site. The launches were conducted during precipitation events and revealed a consistently simple vertical temperature profile without significant inversions (Fig. 2). All of the 15 recorded profiles crossed $0^{\circ} \mathrm{C}$ only once, an average 

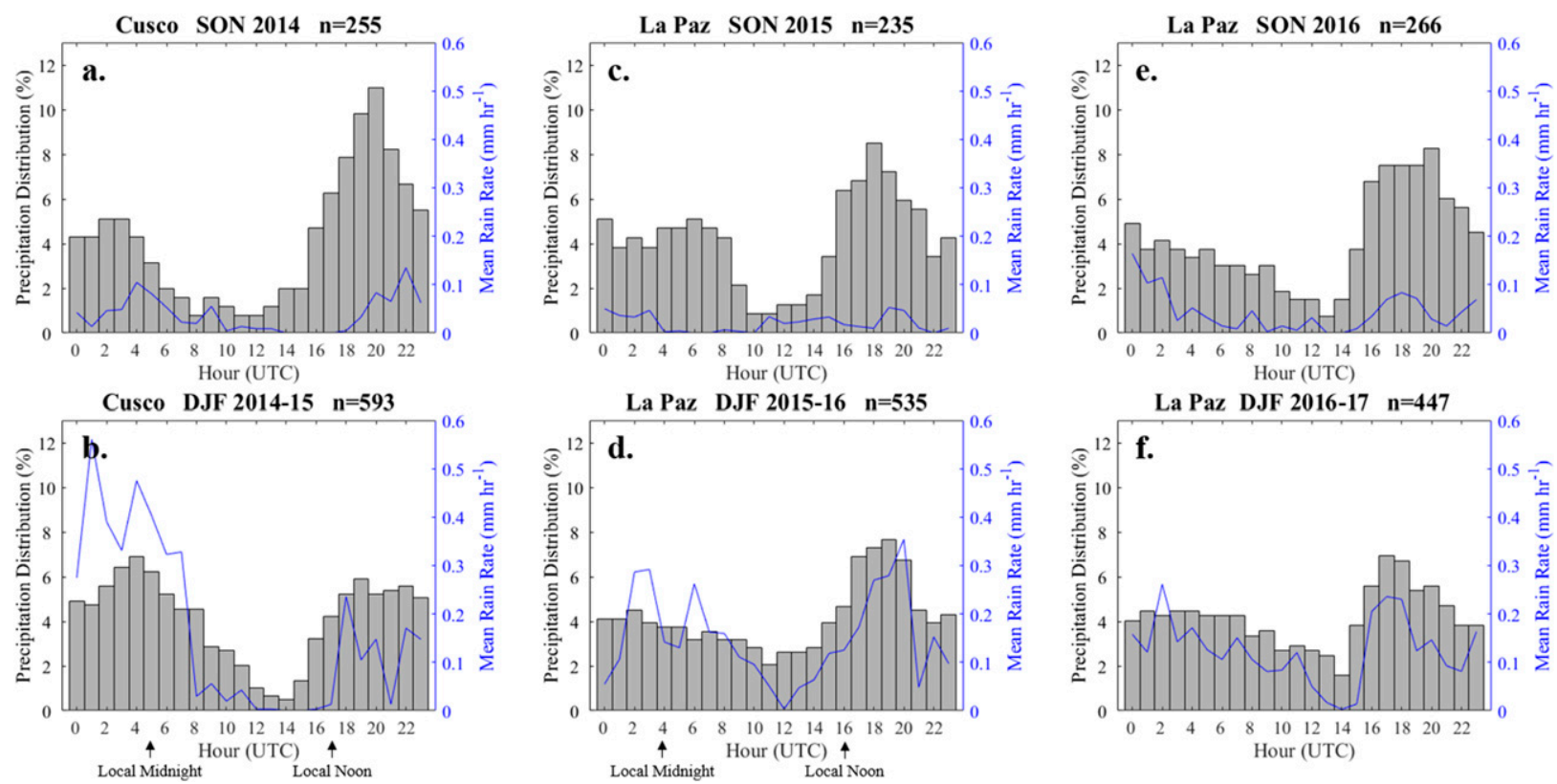

FIG. 3. Hourly distributions of precipitation detected by the MRR at Cusco (Sep 2014-Feb 2015, 189 events) during (a) SON 2014 and (b) DJF 2014-15 and at La Paz (Oct 2015-Feb 2017, 347 events; Sep 2016-Feb 2017, 104 events) during (c) SON 2015, (d) DJF 2015-16, (e) SON 2016, and (f) DJF 2016-17; results are shown by the gray bars. The blue line is the mean hourly accumulated precipitation measured at SPZO in Cusco and the collocated meteorological station in La Paz. Here, $n=$ the number of hours in the sample shown in each histogram.

of $183 \mathrm{~m}$ higher than the temporally closest derived melting-layer height value during the storm. This is similar to findings by Austin and Bernis (1950), in which the bright band existed an average of $253 \mathrm{~m}$ below the $0^{\circ} \mathrm{C}$ level. The discrepancy is likely attributable to the time it takes for the frozen precipitation to melt in response to the ambient temperature.

To provide a context for the upper-level flow during precipitation events in the study area, ERA-Interim data, a set of global atmospheric reanalysis products from the European Centre for Medium-Range Weather Forecasts (ECMWF; Dee et al. 2011), were employed. Point data were extracted to evaluate $500-$ and $250-\mathrm{hPa}$ winds over the location of the MRR during four case studies. Globally Gridded Satellite (GridSat; Knapp et al. 2011) B1 IR brightness temperature imagery for the synoptic hour closest to the middle of each case provided a qualitative analysis of the horizontal extent of each event. Additionally, National Oceanic and Atmospheric Administration (NOAA) Global Data Assimilation System (GDAS) $0.5^{\circ}$ data were used to create backward trajectories with the NOAA Hybrid SingleParticle Lagrangian Integrated Trajectory (HYSPLIT) model for case studies in La Paz and Cusco. Trajectories started at 4000,5000 , and $6000 \mathrm{~m}$ at the location of the MRR during the hour in which the storm began, and ended $72 \mathrm{~h}$ prior. The HYSPLIT model may not accurately represent precise locations of moisture sources during periods of weak flow, and the high terrain and sharp relief of the study area might impact its performance. However, these trajectories still permit the examination of areas from which air parcels within the case studies likely originated.

\section{Results}

\section{a. Overview}

The MRR and data from both Cusco and $\mathrm{La} \mathrm{Paz}$ revealed distinct patterns in the diurnal cycle of precipitation at each location. A summary of precipitation occurrence (Fig. 3), when there was any echo detected by the MRR in the vertical profile, shows that both locations exhibited local maxima in the distribution of precipitation in the afternoon (1700-2000 UTC, 13001600 LT at La Paz and 1200-1500 LT at Cusco) and a second before local midnight (0000-0400 UTC, 20000000 LT at La Paz and 1900-2300 LT at Cusco). The greatest difference in magnitude between the afternoon and overnight local maxima occurred during SON 2014 in Cusco (Fig. 3a). The afternoon maximum was frequently accompanied by a local maximum in mean rain rate, whereas the nighttime maximum was associated with a peak in rain rate primarily in DJF (Fig. 3). These corresponding maxima were especially clear at Cusco (Figs. 3a,b). However, in La Paz the afternoon local 

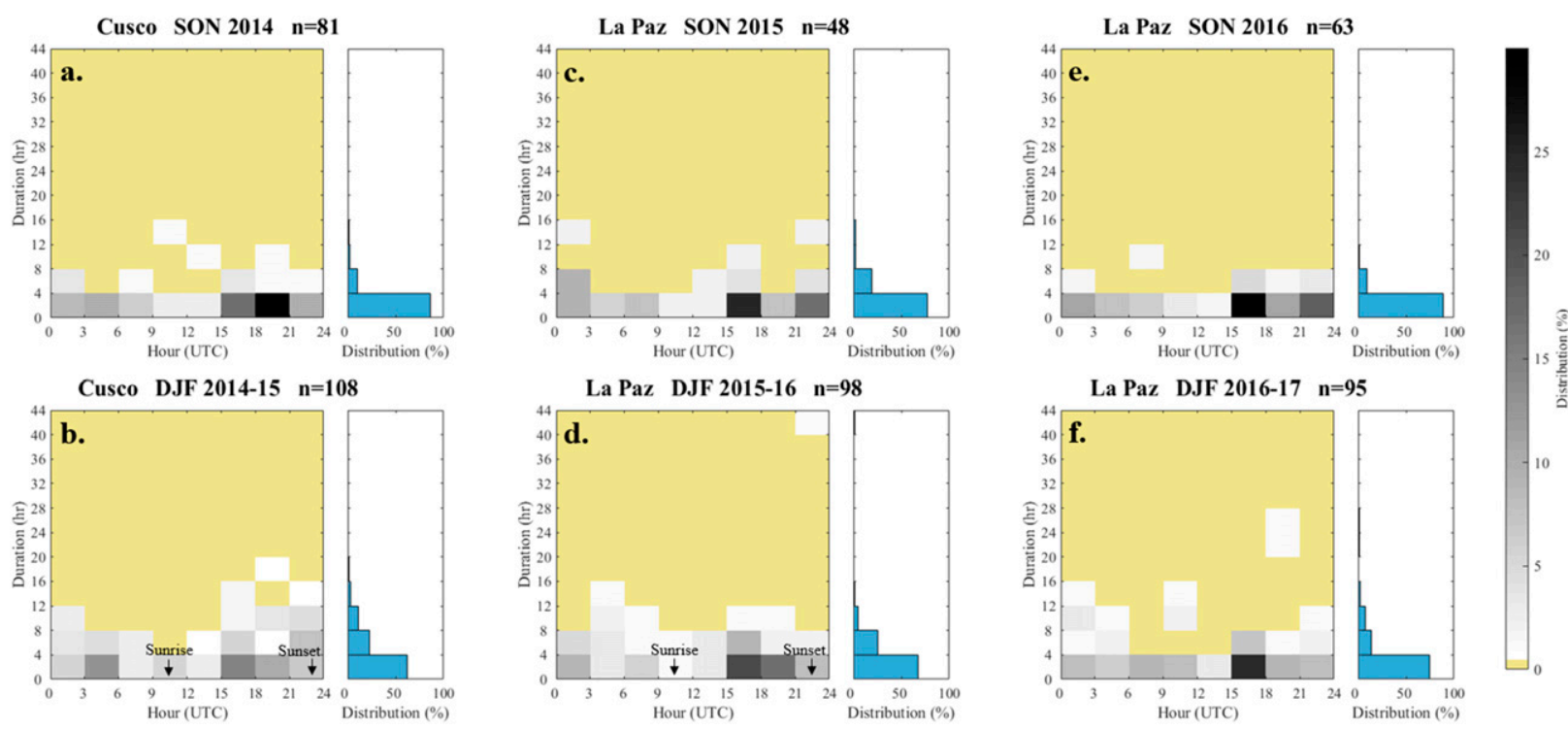

FIG. 4. Scatter density plots showing the joint frequency of the hour in which storms with precipitation reaching the surface began and their duration at Cusco for (a) SON 2014, (b) DJF 2014-15, and at La Paz for (c) SON 2015, (d) DJF 2015-16, (e) SON 2016, and (f) DJF 2016-17. Histograms showing the distribution of the durations for each season. A maximum of $3 \mathrm{~h}$ with no surface precipitation is allowed before a new storm begins. Here, $n=$ the number of events assessed in each plot.

maxima were well defined while the nighttime precipitation was spread over a wider period and the local maxima were not as sharp (Figs. 3c-f).

Storms of less than 4-h duration occurred during all seasons and at all times of the day, and most frequently between 1500 and 2100 UTC (1100-1700 LT at La Paz and 1000-1600 LT at Cusco; Fig. 4). Median storm durations at the Cusco and La Paz MRR sites were less than $\sim 3 \mathrm{~h}$ (Table 2). The highest mean rain rate at each site occurred during hours with storms lasting a median of $1.3 \mathrm{~h}$ in Cusco and $2.1 \mathrm{~h}$ in La Paz. Longer-duration storms $(>12 \mathrm{~h})$ did occur, primarily in DJF as compared with SON at both sites (Fig. 4). Since the sample size of these long-duration events is small $(n=12)$, the data are insufficient to address their diurnal variation.

A seasonal pattern of precipitation is also evident in the MRR data. As expected, more events and higher rain rates occurred in the middle of the wet season (DJF) than in the drier season of austral spring (SON; Table 3; Fig. 4). The difference in the number of total events was highest during the 2015-16 season in La Paz, when only 48 events were recorded in SON while 98 events were recorded in DJF. Apart from JJA 2016 in La Paz (which has a relatively small sample size; $n=9$ ), DJF featured the longest events and highest mean rain rates out of all other seasons in the dataset (Table 3; Figs. 4b,d,f). This was particularly true in Cusco during DJF 2014/15. The shortest median event durations occurred in Cusco during SON 2014, and in La Paz during austral fall (MAM) 2016 and SON 2016. Additionally, these seasons corresponded with values in the bottom half of mean rain rates across all seasons.

Analysis of the derived median melting-layer height data uncovered differences between the distribution of the heights over La Paz and Cusco (Table 4). Quantitatively, the melting-layer height was at or above $5000 \mathrm{~m}$ $30 \%$ of the time in La Paz as opposed to $17 \%$ of the time in Cusco. During stratiform precipitation events with total precipitation accumulation in the top quartile of all stratiform events, the mean and median melting-layer heights were lower than the mean and median values for Cusco, but higher in La Paz (Table 4).

There were similarities in the daily and seasonal patterns of the melting-layer height in the two locations (Fig. 5; Table 5). Melting-layer height values varied by $300 \mathrm{~m}$ to $1050 \mathrm{~m}$ among storms at any given time (Fig. 5). Consistent with the diurnal cycle of surface air temperature, median melting-layer height values were higher in the afternoon and evening (1500-0000 UTC, 1100-2000 LT at La Paz and 1000-1900 LT at Cusco) and lower in the early to midmorning (0600-1500 UTC, 0200-1100 LT at La Paz and 0100-1000 LT at Cusco; Fig. 5). A seasonal pattern in melting-layer height values coincided between La Paz and Cusco. The lowest median melting-layer heights occurred during JJA 2016 when median values only reached $4401 \mathrm{~m}$ in La Paz (Table 6). During DJF, median melting-layer height values in 2014-15, 2015-16, and 2016-17 respectively reached 
TABLE 2. Duration and number of precipitation events that began during 1300-1800,1900-0000, 0100-0600, and 0700-1200 UTC at La Paz and Cusco, as well as the mean hourly accumulated precipitation during each period.

\begin{tabular}{llcccc}
\hline \hline Location & \multicolumn{1}{c}{ Period } & Period (UTC) & Median event duration $(\mathrm{h})$ & No. of events & Rain rate $\left(\mathrm{mm} \mathrm{h}^{-1}\right)$ \\
\hline Cusco & Midday & $1300-1800$ & 3.1 & 61 & 0.02 \\
& Afternoon & $1900-0000$ & 2.2 & 66 & 0.13 \\
& Overnight & $0100-0600$ & 1.3 & 46 & 19 \\
\multirow{5}{*}{ La Paz } & Early morning & $0700-1200$ & 0.7 & 138 & 0.20 \\
& Midday & $1300-1800$ & 2.0 & 92 & 0.07 \\
& Afternoon & $1900-0000$ & 2.1 & 77 & 0.06 \\
& Overnight & $0100-0600$ & 1.6 & 40 & 0.08 \\
\hline
\end{tabular}

$4850 \mathrm{~m}$ in Cusco, with even higher values of 5064 and $4890 \mathrm{~m}$ in La Paz (Table 6).

\section{b. Case studies}

Four events were chosen to highlight the diversity of precipitation characteristics observed in the dataset. The representativeness of these case studies is shown in Fig. 6, regarding the median event melting-layer heights and when the middle of the events occurred.

\section{1) LA PAZ, 24 JANUARY 2017}

On 24 January 2017, a primarily stratiform event with embedded convective precipitation elements began at approximately 1600 UTC (1200 LT) and lasted until 2000 UTC (1600 LT) with storm total precipitation in the top quartile of the La Paz dataset (Fig. 7; Table 7). Similar to the subsequent case studies, air parcels for this event originated from the east and north in the Amazon basin and traveled in northerly (6000-m trajectory) and northeasterly (5000- and 4000-m trajectories) directions toward La Paz (Fig. 7a). A rawinsonde launched at 1655 UTC (1255 LT) recorded a simple vertical temperature profile that crossed the $0^{\circ} \mathrm{C}$ isotherm at $4767 \mathrm{~m}$ (Figs. 7b,c). This temperature profile not only agrees with the simple profiles recorded by several other rawinsonde launches, but it also verifies the values of the meltinglayer height algorithm for this storm. Winds recorded by the rawinsonde had a consistently northerly component throughout the profile. The event produced $11.4 \mathrm{~mm}$ of precipitation, corresponding to a mean rain rate of $2.85 \mathrm{~mm} \mathrm{~h}^{-1}$. The average surface temperature throughout the precipitation was $12.1^{\circ} \mathrm{C}$ as measured by a meteorological station collocated with the MRR (Table 7). The melting-layer height had a median value of $4863 \mathrm{~m}$ during the event.

\section{2) Cusco, 8 October 2014}

A long-duration continuous precipitation event impacted Cusco on 8 October 2014, beginning at approximately 0030 UTC (1930 LT) with a convective character before quickly transitioning to a stratiform character and persisting until 0630 UTC (0130 LT; Fig. 8; Table 7). ERA-Interim winds at 0600 UTC (0100 LT) were from the southeast at $5.9 \mathrm{~m} \mathrm{~s}^{-1}$ at $500 \mathrm{hPa}$ and from the southwest at $8.0 \mathrm{~m} \mathrm{~s}^{-1}$ at $250 \mathrm{hPa}$ (Table 7). The HYSPLIT backward air trajectories (Fig. 8a) show moisture originating from the east and northeast of Cusco 3 days prior at 4000, 5000, and $6000 \mathrm{~m}$. At 0000 UTC (1900 LT), widespread cloudiness covered an area from southeast to northwest of Cusco, as well as to the north in the foothills and the Amazon basin. The mean surface temperature observed at SPZO (1.3 km from the MRR) during this event was $9.8^{\circ} \mathrm{C}$. Rain rates throughout the storm averaged $2.77 \mathrm{~mm} \mathrm{~h}^{-1}$, resulting in storm accumulated precipitation of $16.6 \mathrm{~mm}$, in the top quartile of the Cusco dataset. The melting-layer height during this event is

TABLE 3. Seasonal duration and number of precipitation events during DJF, MAM, JJA, and SON at La Paz and Cusco, as well as the mean hourly accumulated precipitation during each season.

\begin{tabular}{llccc}
\hline \hline Location & \multicolumn{1}{c}{ Period } & Median event duration $(\mathrm{h})$ & No. of events & Rain rate $\left(\mathrm{mm} \mathrm{h}^{-1}\right)$ \\
\hline \multirow{2}{*}{ Cusco } & SON 2014 & 0.9 & 81 & 0.04 \\
& DJF 2014-15 & 3.3 & 108 & 0.18 \\
La Paz & SON 2015 & 1.6 & 48 & 0.02 \\
& DJF 2015-16 & 1.8 & 98 & 0.15 \\
& MAM 2016 & 1.2 & 34 & 0.01 \\
& JJA 2016 & 2.9 & 9 & 0.01 \\
& SON 2016 & 1.3 & 63 & 0.04 \\
& DJF 2016-17 & 2.0 & 95 & 0.12 \\
\hline
\end{tabular}


TABLE 4. Summary of computed melting-layer height $(\mathrm{m})$ statistics from all events, and from predominantly stratiform events with storm total precipitation accumulation $>75$ th percentile (Cusco: 18 events, 75th percentile $=5.7 \mathrm{~mm}$; La Paz: 27 events, 75 th percentile $=5.6 \mathrm{~mm})$.

\begin{tabular}{|c|c|c|c|c|}
\hline & \multicolumn{2}{|c|}{ All events } & \multicolumn{2}{|c|}{$\begin{array}{l}>75 \text { th percentile } \\
\text { stratiform events }\end{array}$} \\
\hline & Cusco & La Paz & Cusco & $\mathrm{La} \mathrm{Paz}$ \\
\hline Max & 5300 & 5363 & 5300 & 5310 \\
\hline Min & 4238 & 4065 & 4304 & 4065 \\
\hline Mean & 4820 & 4873 & 4808 & 4883 \\
\hline Median & 4839 & 4884 & 4822 & 4907 \\
\hline Std dev & 187 & 231 & 196 & 254 \\
\hline
\end{tabular}

easily identifiable and ranged between 4729,4915 , and $4304 \mathrm{~m}$ at the beginning, middle, and end of the precipitation, respectively (Figs. 8b,c).

\section{3) LA PaZ, 25 February 2016}

A 42-h-duration event at $\mathrm{La}$ Paz consisting of intermittent radar echoes with less than 3-h breaks between incidents of precipitation began on 24 February 2016. For this analysis, the intermittent precipitation shown in Figs. 9b and 9c between 1400 UTC (1000 LT) 25 February to just after 1400 UTC (1000 LT) 26 February will be the focus. During the event at 0000 UTC (2000 LT), ERA-Interim winds at $500 \mathrm{hPa}$ were from the southwest at $7.1 \mathrm{~m} \mathrm{~s}^{-1}$ and from the southwest at $2.1 \mathrm{~m} \mathrm{~s}^{-1}$ at $250 \mathrm{hPa}$ (Table 7). The backward air trajectory shows air parcels moving from the northeast toward $\mathrm{La} \mathrm{Paz}$ and originating in the foothills of the Andes to the east 3 days prior at 4000 and $5000 \mathrm{~m}$ (Fig. 9a). The 6000 -m trajectory is particularly anomalous and shows moisture traveling toward La Paz from the southeast and originating in Paraguay. Widespread cloud cover paralleled the central cordilleras of the Andes at 0000 UTC (2000 LT) 26 February 2016, with additional clouds extending well to the north of La Paz (Fig. 9a). The precipitation was primarily stratiform in character with an almost constant melting-layer height throughout, beginning at an altitude of $5050 \mathrm{~m}$ and rising slightly to $5090 \mathrm{~m}$ by the end of the event (Figs. 9b,c). The median melting-layer height reached $5129 \mathrm{~m}, 266 \mathrm{~m}$ higher than the case study on 24 January 2017, despite identical mean surface temperatures of $12.1^{\circ} \mathrm{C}$ (Table 7). Mean rain rates during the event were $1.01 \mathrm{~mm} \mathrm{~h}^{-1}$, in part due to the frequent breaks in precipitation. The meteorological station recorded $24.2 \mathrm{~mm}$ of accumulated precipitation over the 24-h period.

\section{4) Cusco, 15 January 2015}

On 15 January 2015, an unusually strong convective precipitation event began at 1730 UTC (1230 LT) at the location of the MRR in Cusco and lasted approximately $2 \mathrm{~h}$ until 1930 UTC (1430 LT; Fig. 10; Table 7). At 1800 UTC (1300 LT), before the heaviest precipitation began, the ERA-Interim reanalysis data show that winds at $500 \mathrm{hPa}$ (approximately $5890 \mathrm{~m}$ ) were out of the southwest at $4.8 \mathrm{~m} \mathrm{~s}^{-1}$ (Table 7). At $250 \mathrm{hPa}$, the winds shifted to the northwest at $8.0 \mathrm{~m} \mathrm{~s}^{-1}$. The
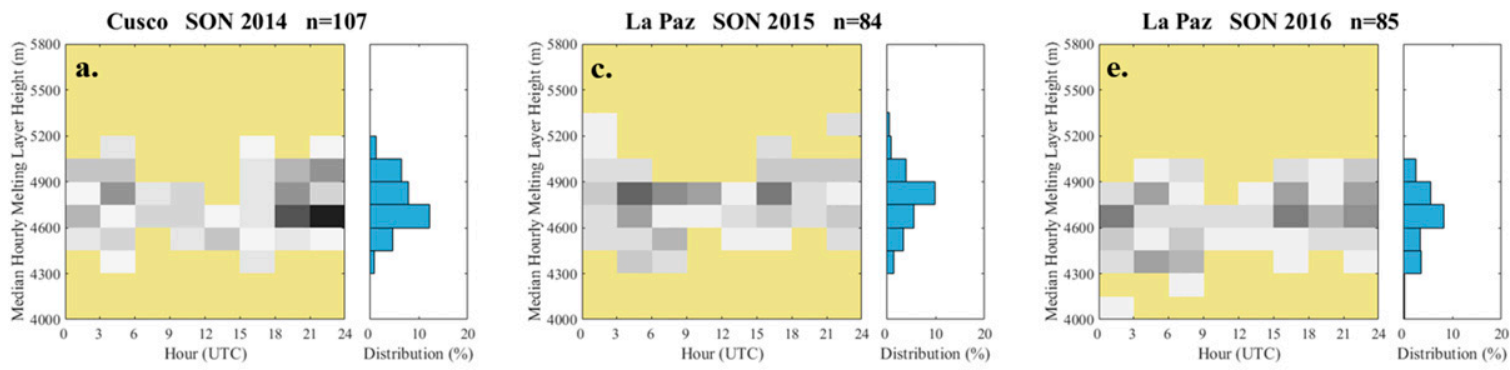

La Paz DJF 2015-16 n=235
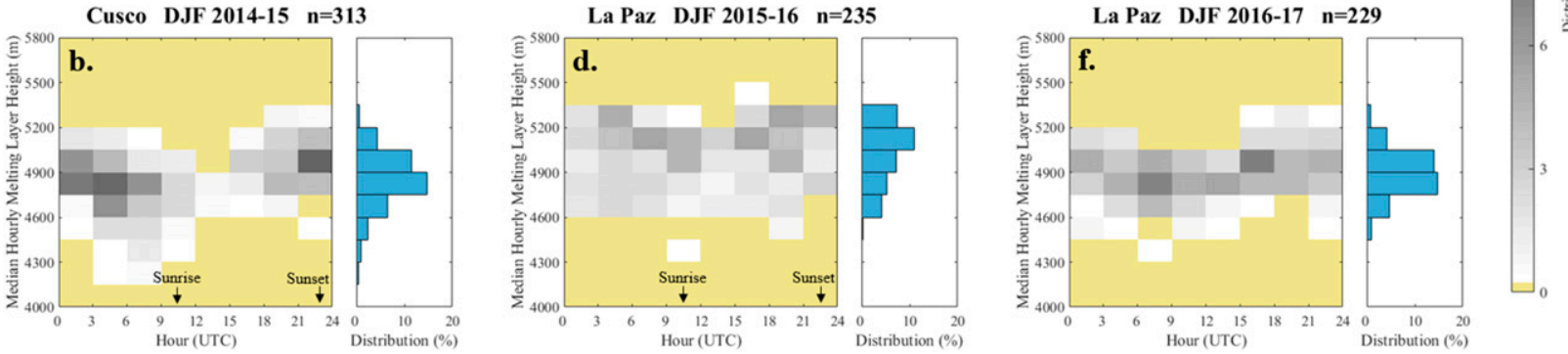

FIG. 5. Scatter density plots showing the diurnal pattern of the median hourly melting-layer height at Cusco for (a) SON 2014, (b) DJF 2014-15, and at La Paz for (c) SON 2015, (d) DJF 2015-16, (e) SON 2016, and (f) DJF 2016-17. Histograms show the distribution of the median melting-layer height values. Here, $n=$ the number of hours assessed in each plot. 
TABLE 5. Daily melting-layer height statistics for 1300-1800, 19000000, 0100-0600, and 0700-1200 UTC at La Paz and Cusco.

\begin{tabular}{llccc}
\hline \hline Location & \multicolumn{1}{c}{ Period } & $\begin{array}{c}\text { Period } \\
\text { (UTC) }\end{array}$ & $\begin{array}{c}\text { Median melting- } \\
\text { layer height }(\mathrm{m})\end{array}$ & $\begin{array}{c}\text { Std } \\
\text { dev }(\mathrm{m})\end{array}$ \\
\hline Cusco & Midday & $1300-1800$ & 4859 & 189 \\
& Afternoon & $1900-0000$ & 4925 & 170 \\
& Overnight & $0100-0600$ & 4809 & 179 \\
\multirow{5}{*}{ La Paz } & Early morning & $0700-1200$ & 4745 & 169 \\
& Midday & $1300-1800$ & 4919 & 192 \\
& Afternoon & $1900-0000$ & 4940 & 229 \\
& Overnight & $0100-0600$ & 4833 & 255 \\
& Early morning & $0700-1200$ & 4841 & 219 \\
\hline
\end{tabular}

HYSPLIT backward air trajectories beginning at 4000 , 5000 , and $6000 \mathrm{~m}$ in altitude suggest that the moisture for the convective event originated not from the east as with the previous case studies, but from the northwest (Fig. 10a). GridSat B1 imagery from 1800 UTC (1300 LT) shows that the focus of the cloudiness was to the north in the foothills, with scattered cloudiness around Cusco (Fig. 10a). The meteorological variables recorded at SPZO show a mean surface temperature of $16.8^{\circ} \mathrm{C}$ throughout the event and $0.8 \mathrm{~mm}$ of accumulated precipitation. However, reflectivities greater than $30 \mathrm{dBZ}$ (Fig. 10b) suggest that the MRR experienced localized rain rates higher than the $0.4 \mathrm{~mm} \mathrm{~h}^{-1}$ recorded $1.3 \mathrm{~km}$ away at SPZO.

The convective nature of the precipitation is evident in the MRR profiles of reflectivity and Doppler velocity shown in Figs. 10b and 10c. While the lower portions of the echo have higher radar reflectivity and downward Doppler velocities as compared with higher altitudes, strong vertical motions inhibit the formation of a distinct melting-layer height. High reflectivities near the surface of the storm attenuate MRR-observed reflectivities at higher altitudes. Attenuated reflectivity values higher than $30 \mathrm{~dB} Z$ (which will be lower than the actual values) above $7100 \mathrm{~m}$ just after 1800 UTC (1300 LT) imply the presence of very intense convection with riming and large hydrometeors. Short periods of time with vertical profiles such as these occur during several convective precipitation events in our dataset. During the 2014-15 wet season in Cusco, 20 of 189 events occurred that contained reflectivity values greater than $30 \mathrm{dBZ}$ above $7100-\mathrm{m}$ altitude at some point during the storm. Twentyseven out of 347 events occurred during both the 201516 and 2016-17 wet seasons in La Paz.

\section{Discussion}

The clear patterns observed in the datasets from both $\mathrm{La} \mathrm{Paz}$ and Cusco of afternoon and nighttime precipitation and melting-layer heights can be partially attributed to strong daily fluctuations in surface
TABLE 6. Seasonal melting-layer height statistics for DJF, MAM, JJA, and SON at La Paz and Cusco.

\begin{tabular}{|c|c|c|c|}
\hline Location & Period & $\begin{array}{c}\text { Median } \\
\text { melting-layer } \\
\text { height }(\mathrm{m})\end{array}$ & $\begin{array}{c}\text { Std } \\
\operatorname{dev}(m)\end{array}$ \\
\hline \multirow[t]{2}{*}{ Cusco } & SON 2014 & 4738 & 175 \\
\hline & DJF 2014-15 & 4850 & 185 \\
\hline \multirow[t]{6}{*}{$\mathrm{La} \mathrm{Paz}$} & SON 2015 & 4790 & 179 \\
\hline & DJF 2015-16 & 5064 & 200 \\
\hline & MAM 2016 & 4903 & 189 \\
\hline & JJA 2016 & 4401 & 185 \\
\hline & SON 2016 & 4703 & 191 \\
\hline & DJF 2016-17 & 4890 & 145 \\
\hline
\end{tabular}

temperature that the tropical Andes experience. A minimum in both MRR-detected precipitation and mean rain rate occurred during the early morning hours (0900-1500 UTC, 0500-1000 LT at La Paz and 04000800 LT at Cusco; Fig. 3; Table 2) as surface temperatures approached a diurnal low. The melting-layer heights reached a maximum in the afternoon $(1500$ 0000 UTC, 1100-2000 LT at La Paz and 1000-1900 LT Cusco; Fig. 5; Table 5) associated with a deep, wellmixed planetary boundary layer following daytime surface heating. This convection also resulted in local maxima in rain rate and maxima of MRR-detected precipitation during these hours (Fig. 3).

Long-duration events typically began during the afternoon to early evening (1900-0000 UTC, 1500-2000 LT at La Paz and 1400-1900 LT at Cusco) and overnight (0100-0600 UTC, 2100-0200 LT at La Paz and 2000-0100 LT at Cusco) periods (Fig. 4; Table 2). These events produced second local maxima in mean rain rates during the overnight hours (Fig. 3; Table 2). The postmidnight through sunrise hours (0700-1200 UTC, 0300-0800 LT at La Paz and 0200-0700 LT at Cusco) were characterized by a minimum in melting-layer heights and minima in rain rates as surface temperatures reached a nocturnal minimum. The early morning (0900-1200 UTC, 0500-0800 LT at La Paz and 0400-0700 LT at Cusco) was also typically characterized by the beginning of shorterduration events $(<8 \mathrm{~h}$ in length; Fig. 4$)$, since any precipitation that formed ended quickly due to a largely stabilized atmosphere from overnight cooling. This cycle was also observed by Perry et al. (2014) in Cusco using hourly precipitation data from SPZO, with one maximum in the afternoon and another close to local midnight.

The MRR data confirm the findings and inferences of previous studies (Bendix et al. 2006; Krois et al. 2013; Perry et al. 2014) that nocturnal precipitation is primarily stratiform in character, with a layered structure and a well-defined bright band indicative of weak 

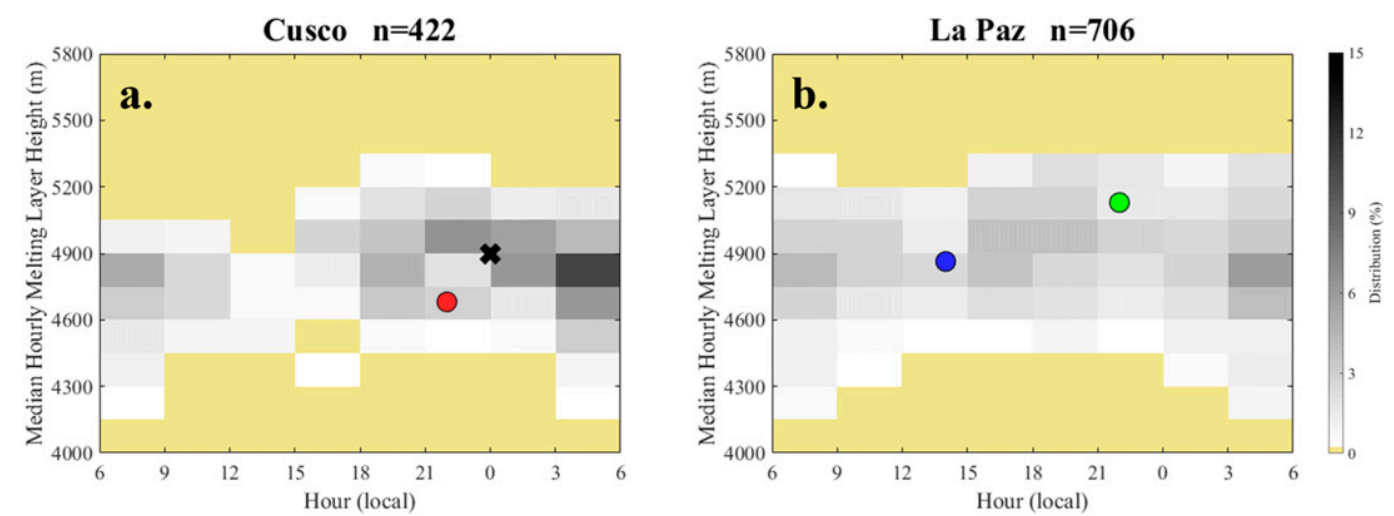

FIG. 6. Diurnal pattern of median hourly melting-layer height at (a) Cusco and (b) La Paz. The red, blue, and green circles are median melting-layer heights for the 7-8 Oct 2014 Cusco, 24 Jan 2017 La Paz, and 25-26 Feb 2016 La Paz case studies, respectively. The black X represents the 15 Jan 2015 event with no visible melting layer. The markers are placed at the midpoint of the events. Here, $n$ is the number of hours assessed in each plot.

vertical air motion (Houze 1997; Yuter et al. 2006). These events were characterized by heavy precipitation, with mean rain rates during the overnight hours (0100-0600 UTC, 2100-0200 LT at La Paz and 2000$0100 \mathrm{LT}$ at Cusco) reaching $0.2 \mathrm{~mm} \mathrm{~h}^{-1}$ in Cusco and $0.08 \mathrm{~mm} \mathrm{~h}^{-1}$ in La Paz (Table 2). Higher rainfall totals resulted from individual events during this period that lasted for several hours. The case study in Cusco that began at 0030 UTC 8 October 2014 produced $16.6 \mathrm{~mm}$ of precipitation over the course of $6 \mathrm{~h}$. In our dataset, longduration stratiform events such as this occurred more commonly during DJF (Fig. 4; Table 3). The long durations during JJA 2016 in La Paz (Table 3) resulted from a small sample $(n=9)$ containing exceptionally long events. Many of the heavy accumulation nighttime events in our dataset (e.g., Cusco, 8 October 2014; Fig. 8), defined as storms with total accumulated precipitation in the top quartile, exhibited convective precipitation at the onset before stratiform precipitation develops.

The common occurrence of stratiform precipitation structure was unreported in the tropical Andes until radarbased studies were performed (Bendix et al. 2006; Perry et al. 2017). Some studies have suggested that nighttime precipitation in the region originates in the Amazon basin from mesoscale convective systems (MCSs; Bendix et al. 2006, 2009; Romatschke and Houze 2010; Chavez and Takahashi 2017). These lowland MCSs form in response to daytime heating or by the convergence of downslope flow, which develops from rapidly cooling high terrain after sunset, with unstable air within the Amazon basin (Bendix et al. 2009; Romatschke and Houze 2010). Daytime heating of mountains induces an upslope valley breeze and precipitation initiates when sufficient moisture flux is present (Giovannettone and Barros 2009). Once precipitation forms over the slopes, evaporatively cooled downslope flow can interact with incoming Amazonian moisture, perpetuating precipitation in the mountain valleys (Giovannettone and Barros 2009; Houze 2014). Overnight when clouds are not present, radiatively cooled downslope flows can interact with Amazonian moisture to yield a nighttime precipitation peak in the valleys (Bendix et al. 2009; Giovannettone and Barros 2009; Mohr et al. 2014). Moisture flux from the South American low-level jet (SALLJ) along the eastern slopes of the Andes can also be impeded by weaker nighttime upslope flows, feeding organized convection at lower elevations (Chavez and Takahashi 2017).

In one explanation, these regions of organized precipitation then proceed to propagate upslope and westward across the study area during the overnight hours (Bendix et al. 2006, 2009; Krois et al. 2013). However, convection that forms along the Andean foothills may be directed to the south and east before development into large MCSs occurs (Romatschke and Houze 2013). Orographic precipitation is commonly associated with a seeder-feeder mechanism that will yield locally enhanced stratiform precipitation structures (Houze 2014; Perry et al. 2014). This may allow for afternoon convection in the tropical Andes that evolves into broader, long-lasting stratiform systems that persist through the night. Chavez and Takahashi (2017) observed nighttime MCSs in the Peruvian Andes that developed broad stratiform precipitation regions downslope and upslope of maximum convective precipitation in the foothills.

The strong El Niño in progress during the collection of the La Paz 2015-16 dataset may be responsible for the more elevated melting-layer heights when compared with Cusco 2014-15 or La Paz 2016-17 (Fig. 5; Table 6). Melting-layer height values were at or above $5000 \mathrm{~m}$ for $47 \%$ of the values during SON-DJF 2015/16 alone. 


\section{a}

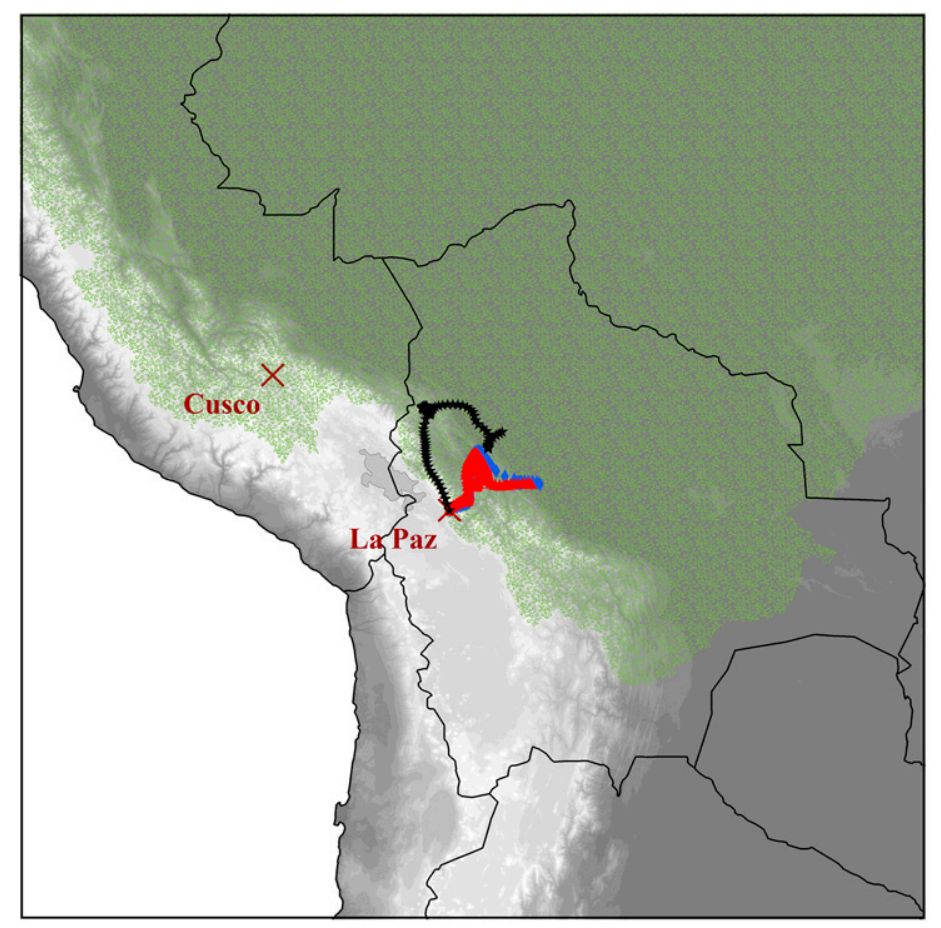

b

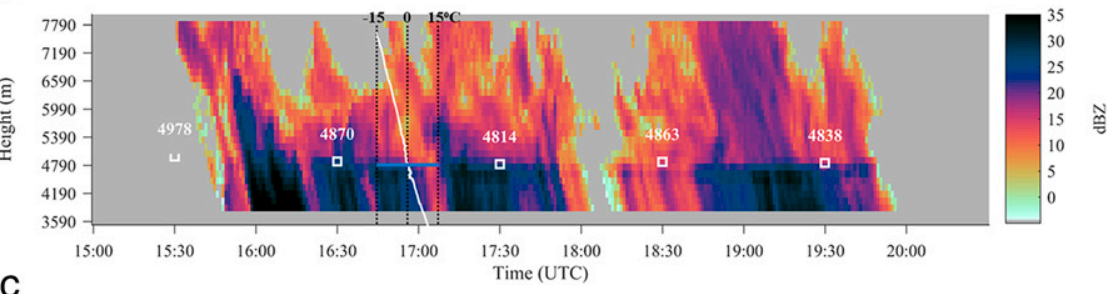

C

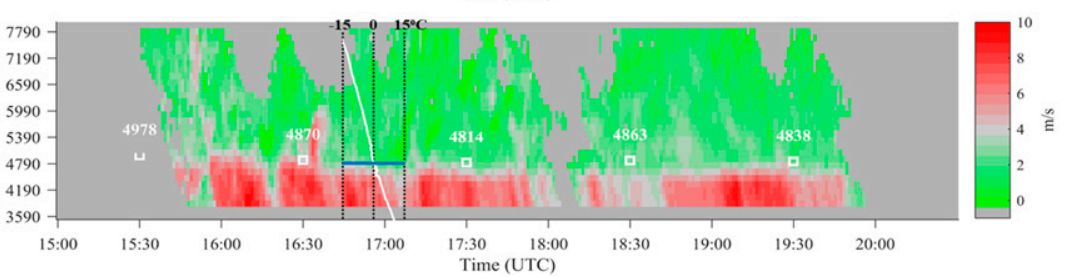

FIG. 7. A primarily stratiform precipitation event occurred over La Paz from 1500 to 2030 UTC 24 Jan 2017. (a) HYSPLIT-derived 72-h backward air trajectories ending at $4000 \mathrm{~m}$ (blue diamonds), $5000 \mathrm{~m}$ (red triangles), and $6000 \mathrm{~m}$ (black stars) from 1600 UTC 21 Jan to 1600 UTC 24 Jan 2017, overlaid onto the central Andes and the Amazon basin. Vertical profiles of the precipitation are shown by (b) reflectivity and (c) Doppler velocity time-height plots. White boxes and numbers indicate median hourly computed melting-layer heights. The rawinsonde-measured vertical temperature profile is overlaid in (b) and (c). The temperature profile is centered at the time when the rawinsonde was launched, and the blue horizontal line indicates the $0^{\circ} \mathrm{C}$ level.

A series of events in La Paz in late February 2016 (one shown in Fig. 9) exhibited exceptionally high meltinglayer heights (Fig. 6) with a combined median value of $5165 \mathrm{~m}$, likely due in part to anomalously elevated temperatures at the surface. Schauwecker et al. (2017) demonstrated the utility of surface temperatures for extrapolating the altitude of the melting layer with an environmental lapse rate of $6.5^{\circ} \mathrm{Cm}^{-1}$. Using this principle for the case study in La Paz on 25 February 2016 (Fig. 9), median extrapolated melting-layer heights lie at $5302 \mathrm{~m}$, only $173 \mathrm{~m}$ higher than the median value detected by the MRR data. However, the extrapolated median value for the 24 January 2017 event (Fig. 7) is $439 \mathrm{~m}$ higher than the melting-layer height detected by 
TABLE 7. Meteorological and MRR statistics for the case studies. Upper-level winds are derived from ERA-Interim data for the grid cell closest to the MRR at the event location and at the reanalysis hour closest to the middle of each event. Surface meteorological variables were obtained from SPZO and a station collocated with the La Paz MRR. Duration values are calculated using 3-h breaks and, therefore, represent parts of the event that may exist outside of the range of the MRR image.

\begin{tabular}{|c|c|c|c|c|}
\hline & Cusco, 15 Jan 2015 & Cusco, 8 Oct 2014 & La Paz, 25 Feb 2016 & La Paz, 24 Jan 2017 \\
\hline Storm total precipitation $(\mathrm{mm})$ & 0.8 & 16.6 & 24.2 & 11.4 \\
\hline Average temperature $\left({ }^{\circ} \mathrm{C}\right)$ & 16.8 & 9.4 & 12.1 & 12.1 \\
\hline Total duration $(\mathrm{h})$ & 3.3 & 5.8 & 42.2 & 5.2 \\
\hline Median melting-layer height (m) & - & 4681 & 5129 & 4863 \\
\hline 500-hPa wind speed $\left(\mathrm{m} \mathrm{s}^{-1}\right)$ & 4.8 & 5.9 & 7.1 & 4.8 \\
\hline 500-hPa wind direction $\left(^{\circ}\right)$ & 207 & 125 & 218 & 302 \\
\hline 250-hPa wind speed $\left(\mathrm{m} \mathrm{s}^{-1}\right)$ & 8.0 & 8.0 & 2.1 & 12.2 \\
\hline 250-hPa wind direction $\left(^{\circ}\right)$ & 343 & 242 & 227 & 324 \\
\hline
\end{tabular}

the algorithm. This suggests that additional factors such as the intensity and duration of precipitation also play a role in determining where the melting-layer height lies.

Observations such as these of high melting-layer heights are important because they are consistent with the reported rise in ELA and corresponding glacier retreat in the central Andes (Rabatel et al. 2013; Salzmann et al. 2013). Assuming regional coherency of the melting-layer height during long-duration stratiform precipitation events, melting-layer heights above 5000-m altitude imply that on occasion rain may occur in alpine zones such as on the Nevado Chacaltaya (Perry et al. 2017), where a glacier existed until 2010 (Rabatel et al. 2013), and other glacier regions in the tropical Andes. Although the altitude of the Quelccaya summit lies well above any melting-layer height detected in Cusco, a weather sensor presently located there $(5640 \mathrm{~m})$ suggests that liquid precipitation may occur at times, even at that elevation (Perry et al. 2017).

The geography of the study sites, such as distance from the Amazon basin, the major proximal source of moisture for the central Andes (Garreaud 1999, 2000; Garreaud et al. 2003; Perry et al. 2014), may explain a portion of the variability observed in the diurnal cycle of precipitation between La Paz and Cusco. As measured from satellite imagery, $\mathrm{La} \mathrm{Paz}$ is $\sim 28 \mathrm{~km}$ from the upper forest boundary of the Amazon as compared with $\sim 56 \mathrm{~km}$ for Cusco. Differences in the behavior of precipitation at $\mathrm{La}$ Paz and Cusco may also be explained by a difference in atmospheric baseline states between the two datasets, particularly regarding ENSO phase. The 2015-16 MRR data from La Paz were collected during a strong El Niño, with a September 2015-February 2016 mean multivariate ENSO index (MEI; Wolter and Timlin 1993) value of +2.2 . Anomalously higher tropospheric temperatures prevailed across the tropical Andes, following the recognized pattern of strong El Niño events (Vuille 1999; Wagnon et al. 2001). However, the 2014-15 Cusco and 2016-17 La Paz datasets were collected during relatively neutral phases of ENSO (2014-15, mean MEI $=+0.5$; 2016-17, mean MEI $=-0.2$ ). Daily maximum surface temperatures recorded at SPZO were $0.9^{\circ} \mathrm{C}$ greater on average from 1 November 2015 to 31 March 2016 than during the same period averaged between 2014-15 and 2016-17. The average temperature difference recorded at SLLP was $0.7^{\circ} \mathrm{C}$ greater.

A fundamental limitation of our dataset is the sequential rather than synchronous collection periods of the Cusco and La Paz MRR data. This makes it difficult to ascertain whether the observed differences in precipitation patterns are more a result of geography or interannual climatic variability influenced by ENSO and other forcings. Several factors could have contributed to the higher melting-layer heights and earlier precipitation maxima in La Paz relative to Cusco in the different years including altered atmospheric patterns due to a strong El Niño or location with respect to airflow source regions in the Amazon basin. Our dataset does not permit us to distinguish between these potential contributions.

\section{Conclusions}

In this study, vertically pointing MRR data were utilized to investigate the precipitation patterns at two sites in the tropical Andes. The diurnal cycle, distribution, and melting-layer height of precipitation events were analyzed, along with the trajectories from which low-level air originated. A bimodal pattern in precipitation occurrence and rain rate was evident at both La Paz, Bolivia, and Cusco, Peru, with local maxima in the precipitation distribution in the afternoon and overnight. Brief convective cells with heavier precipitation were common in all precipitation events. However, the nighttime peak was dominated by longer and more stratiform precipitation. Long-duration nighttime stratiform events primarily occurred during the DJF seasons. Consistent with the diurnal cycle of surface temperature in the tropical Andes, melting-layer 


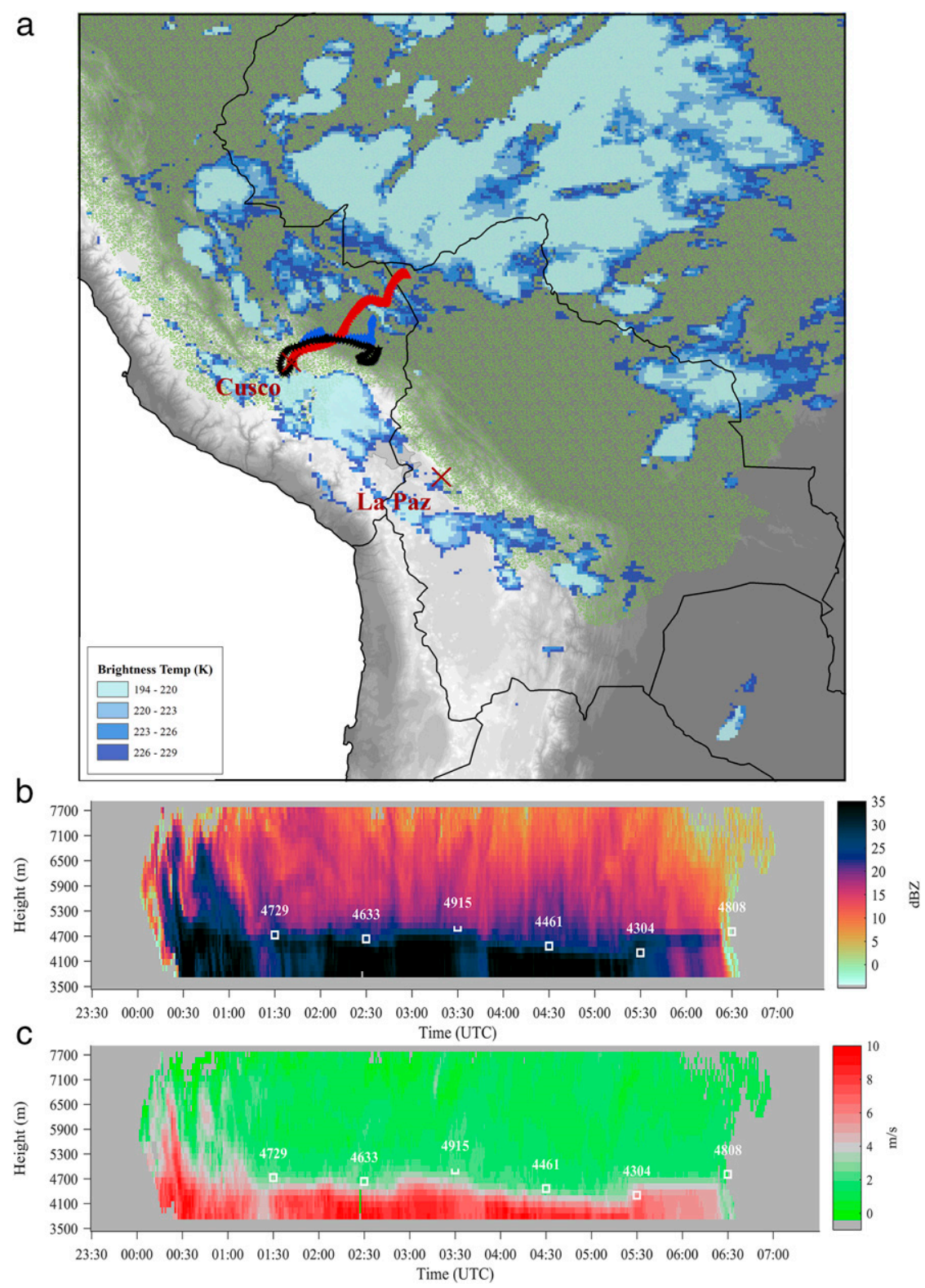

FIG. 8. A primarily stratiform precipitation event occurred over Cusco from 2330 UTC 7 Oct to 0730 UTC 8 Oct 2014. (a) GridSat B1 IR brightness temperature imagery for 0000 UTC 8 Oct 2014 and HYSPLIT-derived 72-h backward air trajectories ending at $4000 \mathrm{~m}$ (blue diamonds), $5000 \mathrm{~m}$ (red triangles), and $6000 \mathrm{~m}$ (black stars) from 0100 UTC 5 Oct to 0100 UTC 8 Oct 2014. Vertical profiles of the precipitation are shown by (b) reflectivity and (c) Doppler velocity time-height plots. White boxes and numbers indicate median hourly computed melting-layer heights.

heights were higher in the afternoon as compared with overnight. The 72-h backward air trajectories from four case studies show predominant moisture advection from the Amazon basin. MRR radar data derived meltinglayer height values show differences in magnitude between La Paz and Cusco, with higher values in $\mathrm{La} \mathrm{Paz}$ particularly during the 2015-16 year. These differences may result from either geography (La Paz is closer to the Amazon rain forest), ENSO phase (the La Paz dataset was collected during a strong El Niño), or a combination of both factors.

Melting-layer heights as high as $5300 \mathrm{~m}$ were derived from the MRR datasets from $\mathrm{La} \mathrm{Paz}$ and Cusco. This elevation is almost as high as the uppermost 


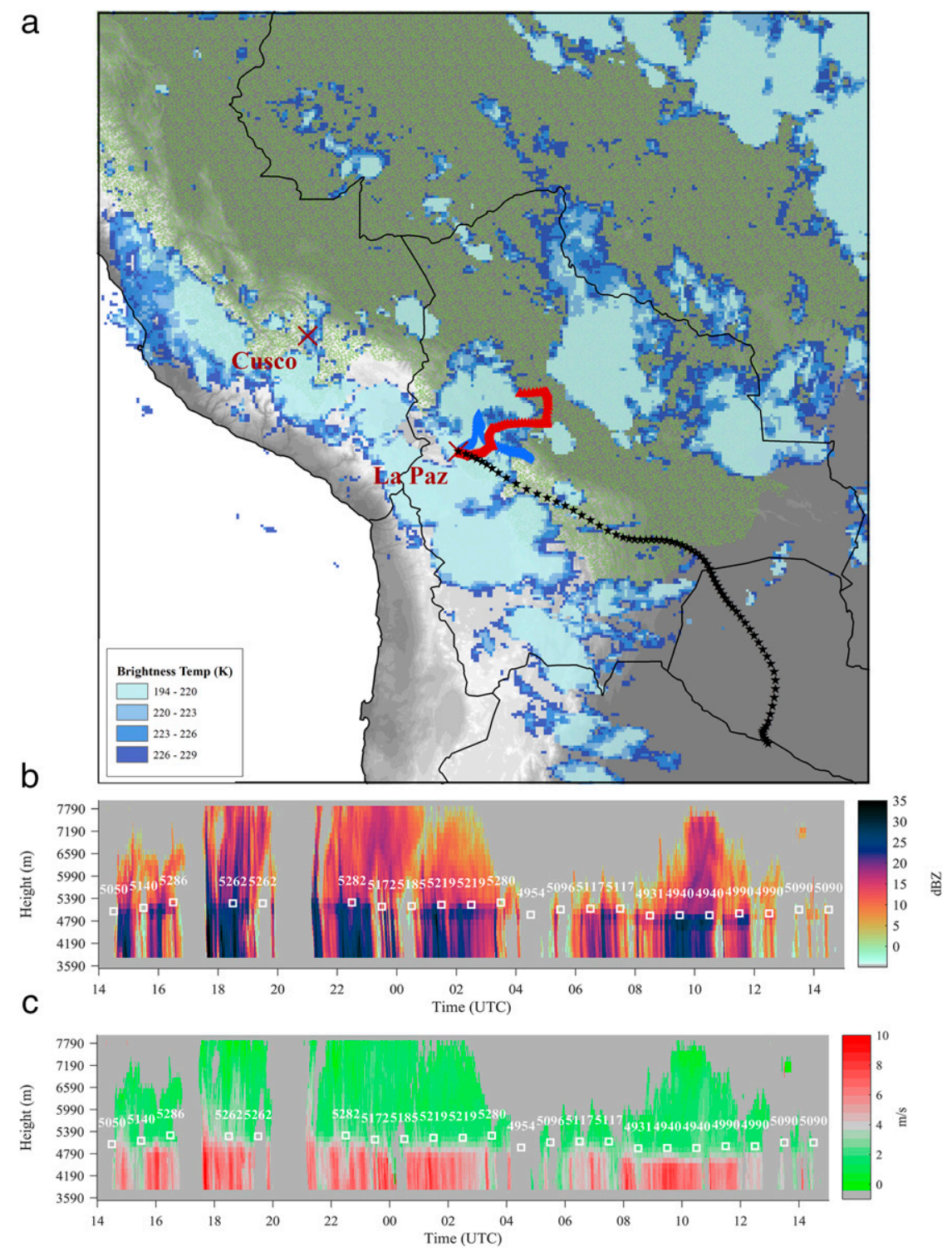

FIG. 9. An intermittent, primarily stratiform precipitation event occurred over La Paz from 1400 UTC 25 Feb to 1430 UTC 26 Feb 2016. (a) GridSat B1 IR brightness temperature imagery for 0000 UTC 26 Feb 2016 and HYSPLIT-derived 72-h backward air trajectories ending at $4000 \mathrm{~m}$ (blue diamonds), $5000 \mathrm{~m}$ (red triangles), and $6000 \mathrm{~m}$ (black stars) from 1500 UTC $22 \mathrm{Feb}$ to 1500 UTC $25 \mathrm{Feb} 2016$. Vertical profiles of the precipitation are shown by (a) reflectivity and (b) Doppler velocity time-height plots. White boxes and numbers indicate median hourly computed melting-layer heights.

ELAs $(5400 \mathrm{~m})$ during exceptionally negative mass balance years on glaciers reported upon by Rabatel et al. (2013). During 2015-16, which coincided with a strong El Niño event, the melting-layer height was at or above $5000 \mathrm{~m}$ for $47 \%$ of the time in La Paz. Melting-layer heights at these altitudes have important implications for ice albedo and on the health of glaciers in the study area. The identified characteristics of precipitation in La Paz promote rising ELAs on glaciers in the region and less glacier mass at lower altitudes. In a warming climate, further increases in the altitude of the melting-layer height and decreases in the frequency of frozen precipitation reaching the glacier surface will result in continued glacier retreat in the central Andes.

Further research is needed in order to disentangle the relationships between the initiation of convection in the region, its development into organized precipitation, 


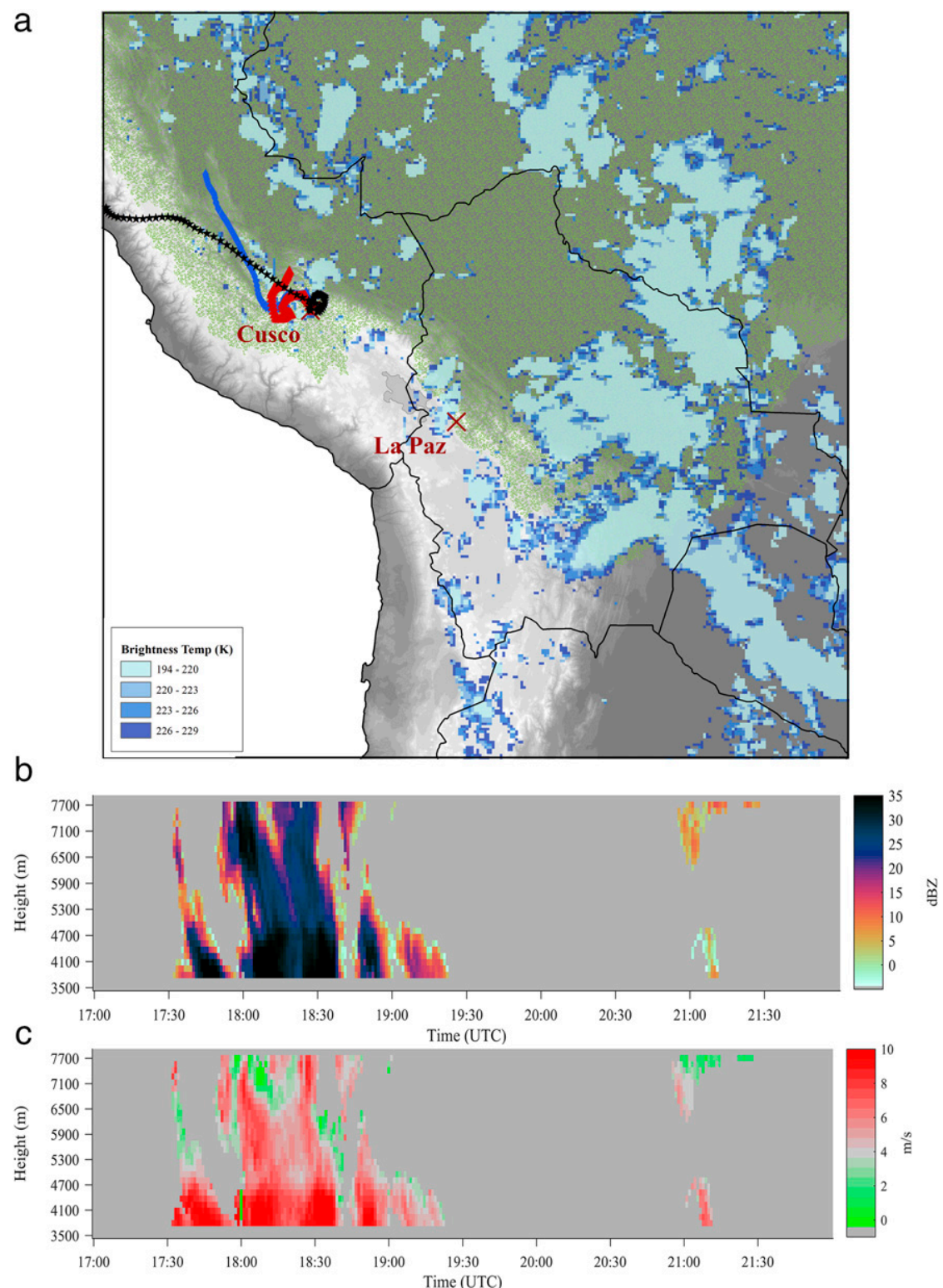

FIG. 10. A strong convective precipitation event occurred over Cusco from 1700 to 2200 UTC 15 Jan 2015. (a) GridSat B1 IR brightness temperature imagery for 1800 UTC 15 Jan 2015 and HYSPLIT-derived 72-h backward air trajectories ending at $4000 \mathrm{~m}$ (blue diamonds), $5000 \mathrm{~m}$ (red triangles), and $6000 \mathrm{~m}$ (black stars) from 1800 UTC 12 Jan to 1800 UTC 15 Jan 2015. Vertical profiles of the precipitation are shown by (a) reflectivity and (b) Doppler velocity time-height plots.

and the direct and indirect influences that these systems have on the tropical Andes weather and climate. Simultaneous MRR observations in both $\mathrm{La} \mathrm{Paz}$ and Cusco would help to uncover the differences between the impact of geography and atmospheric patterns on precipitation behavior between the two locations. Additionally, future research should consider how meltinglayer heights detected over $\mathrm{La} \mathrm{Paz}$ and Cusco relate to melting-layer height values over higher terrain more broadly across the highland region.

Acknowledgments. The source of much of the content in this manuscript is Endries's M.A. thesis (Endries 2017). The authors gratefully acknowledge Ronnie Ascarza, Rimort Chavez, Christian Huggel, Spencer Rhodes, Simone Schauwecker, and Zach Osborne for 
their scientific expertise, data support, and critical eyes. Thanks also go to Guido Mamani and Fabricio Avila for providing technical support for instrumentation. We also acknowledge NOAA's Air Resources Laboratory for the use of the HYSPLIT model. Funding supporting this research was provided by the National Science Foundation through Grants AGS-1347179 (Perry) and AGS-1347491 (Yuter).

\section{REFERENCES}

Austin, P. M., and A. C. Bernis, 1950: A quantitative study of the "bright band" in radar precipitation echoes. J. Meteor., 7, 145-151, https:// doi.org/10.1175/1520-0469(1950)007<0145:AQSOTB>2.0.CO;2.

Bendix, J., R. Rollenbeck, and C. Reudenbach, 2006: Diurnal patterns of rainfall in a tropical Andean valley of southern Ecuador as seen by a vertically pointing K-band Doppler radar. Int. J. Climatol., 26, 829-846, https://doi.org/10.1002/joc.1267.

_- K. Trachte, J. Cermak, R. Rollenbeck, and T. Nauß, 2009: Formation of convective clouds at the foothills of the tropical eastern Andes (south Ecuador). J. Appl. Meteor. Climatol., 48, 1682-1695, https://doi.org/10.1175/2009JAMC2078.1.

Cai, W., and Coauthors, 2014: Increasing frequency of extreme El Niño events due to greenhouse warming. Nat. Climate Change, 4, 111-116, https://doi.org/10.1038/nclimate2100.

Chavez, S. P., and K. Takahashi, 2017: Orographic rainfall hot spots in the Andes-Amazon transition according to the TRMM precipitation radar and in situ data. J. Geophys. Res. Atmos., 122, 5870-5882, https://doi.org/10.1002/2016JD026282.

Christensen, J. H., and Coauthors, 2013: Climate phenomena and their relevance for future regional climate change. Climate Change 2013: The Physical Science Basis, T. F. Stocker et al., Eds., Cambridge University Press, 1217-1308.

Das, S., and A. Maitra, 2011: Some melting layer characteristics at two tropical locations in Indian region. 30th Union Radio Scientifique Internationale General Assembly and Scientific Symp., Istanbul, Turkey, URSI, 1-4, https://doi.org/10.1109/ URSIGASS.2011.6050805.

Dee, D. P., and Coauthors, 2011: The ERA-Interim reanalysis: Configuration and performance of the data assimilation system. Quart. J. Roy. Meteor. Soc., 137, 553-597, https://doi.org/10.1002/qj.828.

Endries, J. L., 2017: Radar-observed characteristics of precipitation in the tropical high Andes of southern Peru and Bolivia. M.A. thesis, Dept. of Geography and Planning, Appalachian State University, 52 pp., http://libres.uncg.edu/ir/ asu/listing. aspx? $\mathrm{id}=21713$.

Falvey, M., and R. D. Garreaud, 2005: Moisture variability over the South American Altiplano during the South American Low Level Jet Experiment (SALLJEX) observing season. J. Geophys. Res., 110, D22105, https://doi.org/10.1029/2005JD006152.

Francou, B., M. Vuille, P. Wagnon, J. Mendoza, and J.-E. Sicart, 2003: Tropical climate change recorded by a glacier in the central Andes during the last decades of the twentieth century: Chacaltaya, Bolivia, $16^{\circ}$ S. J. Geophys. Res., 108, 4154, https:// doi.org/10.1029/2002JD002959.

Garreaud, R. D., 1999: Multiscale analysis of the summertime precipitation over the central Andes. Mon. Wea. Rev., 127, 901-921, https://doi.org/10.1175/1520-0493(1999)127<0901: MAOTSP $>2.0 . \mathrm{CO} ; 2$.

- 2000: Intraseasonal variability of moisture and rainfall over the South American Altiplano. Mon. Wea. Rev., 128,
3337-3346, https://doi.org/10.1175/1520-0493(2000)128<3337: IVOMAR $>2.0 . \mathrm{CO} ; 2$.

-, M. Vuille, and A. C. Clement, 2003: The climate of the Altiplano: Observed current conditions and mechanisms of past changes. Palaeogeogr. Palaeoclimatol. Palaeoecol., 194, 5-22, https://doi.org/10.1016/S0031-0182(03)00269-4.

Giovannettone, J. P., and A. P. Barros, 2009: Probing regional orographic controls of precipitation and cloudiness in the central Andes using satellite data. J. Hydrometeor., 10, 167182, https://doi.org/10.1175/2008JHM973.1.

Hanshaw, M. N., and B. Bookhagen, 2014: Glacial areas, lake areas, and snow lines from 1975 to 2012: Status of the Cordillera Vilcanota, including the Quelccaya ice cap, northern central Andes, Peru. Cryosphere, 8, 359-376, https://doi.org/ 10.5194/tc-8-359-2014.

Houze, R. A., Jr., 1997: Stratiform precipitation in regions of convection: A meteorological paradox? Bull. Amer. Meteor. Soc., 78, 2179-2196, https://doi.org/10.1175/1520-0477(1997)078<2179: SPIROC $>2.0 . \mathrm{CO} ; 2$.

- 2014: Cloud Dynamics. International Geophysics Series, Vol. 104, Academic Press, 496 pp.

Kaser, G., 1999: A review of the modern fluctuations of tropical glaciers. Global Planet. Change, 22, 93-103, https://doi.org/ 10.1016/S0921-8181(99)00028-4.

Knapp, K. R., and Coauthors, 2011: Globally gridded satellite observations for climate studies. Bull. Amer. Meteor. Soc., 92, 893-907, https://doi.org/10.1175/2011BAMS3039.1.

Krois, J., A. Schulte, E. P. Vigo, and C. C. Moreno, 2013: Temporal and spatial characteristics of rainfall patterns in the northern Sierra of Peru-A case study for La Niña to El Niño transitions from 2005 to 2010. Espacio Desarrollo, 25, 23-48.

Kummerow, C., W. Barnes, T. Kozu, J. Shiue, and J. Simpson, 1998: The Tropical Rainfall Measuring Mission (TRMM) sensor package. J. Atmos. Oceanic Technol., 15, 809-817, https:// doi.org/10.1175/1520-0426(1998)015<0809:TTRMMT>2.0.CO;2.

L'hôte, Y., P. Chevallier, A. Coudrain, Y. Lejeune, and P. Etchevers, 2005: Relationship between precipitation phase and air temperature: Comparison between the Bolivian Andes and the Swiss Alps. Hydrol. Sci. J., 50, 989-997, https://doi.org/10.1623/ hysj.2005.50.6.989.

Löffler-Mang, M., M. Kunz, and W. Schmid, 1999: On the performance of a low-cost K-band Doppler radar for quantitative rain measurements. J. Atmos. Oceanic Technol., 16, 379-387, https://doi.org/10.1175/1520-0426(1999)016<0379: OTPOAL $>2.0 . C O ; 2$.

Lundquist, J. D., P. J. Neiman, B. Martner, A. B. White, D. J. Gottas, and F. M. Ralph, 2008: Rain versus snow in the Sierra Nevada, California: Comparing Doppler profiling radar and surface observations of melting level. J. Hydrometeor., 9, 194211, https://doi.org/10.1175/2007JHM853.1.

Maahn, M., and P. Kollias, 2012: Improved Micro Rain Radar snow measurements using Doppler spectra post-processing. Atmos. Meas. Tech., 5, 2661-2673, https://doi.org/10.5194/ amt-5-2661-2012.

Massmann, A. K., J. R. Minder, R. D. Garreaud, D. E. Kingsmill, R. A. Valenzuela, A. Montecinos, S. L. Fults, and J. R. Snider, 2017: The Chilean coastal orographic precipitation experiment: Observing the influence of microphysical rain regime on coastal orographic precipitation. J. Hydrometeor., 18, $2723-$ 2743, https://doi.org/10.1175/JHM-D-17-0005.1.

METEK, 2009: MRR physical basics: version 5.2.0.1. METEK Tech. Manual, 20 pp, http://www.mpimet.mpg.de/fileadmin/atmosphaere/ barbados/Instrumentation/MRR-physical-basics_20090707.pdf. 
Minder, J. R., and D. E. Kingsmill, 2013: Mesoscale variations of the atmospheric snow line over the northern Sierra Nevada: Multiyear statistics, case study, and mechanisms. J. Atmos. Sci., 70, 916-938, https://doi.org/10.1175/JAS-D-12-0194.1.

Mohr, K. I., D. Slayback, and K. Yager, 2014: Characteristics of precipitation features and annual rainfall during the TRMM era in the central Andes. J. Climate, 27, 3982-4001, https:// doi.org/10.1175/JCLI-D-13-00592.1.

Perry, L. B., A. Seimon, and G. M. Kelly, 2014: Precipitation delivery in the tropical high Andes of southern Peru: New findings and paleoclimatic implications. Int. J. Climatol., 34, 197-215, https://doi.org/10.1002/joc.3679.

— , and Coauthors, 2017: Characteristics of precipitating storms in glacierized tropical Andean Cordilleras of Peru and Bolivia. Ann. Amer. Assoc. Geogr., 107, 309-322, https://doi.org/ 10.1080/24694452.2016.1260439.

Peters, G., B. Fischer, and T. Andersson, 2002: Rain observations with a vertically looking Micro Rain Radar (MRR). Boreal Environ. Res., 7, 353-362.

H. Münster, M. Clemens, and A. Wagner, 2005: Profiles of raindrop size distributions as retrieved by microrain radars. J. Appl. Meteor., 44, 1930-1949, https://doi.org/10.1175/ JAM2316.1.

Rabatel, A., and Coauthors, 2013: Current state of glaciers in the tropical Andes: A multi-century perspective on glacier evolution and climate change. Cryosphere, 7, 81-102, https:// doi.org/10.5194/tc-7-81-2013.

Romatschke, U., and R. A. Houze Jr., 2010: Extreme summer convection in South America. J. Climate, 23, 3761-3791, https://doi.org/10.1175/2010JCLI3465.1.

$\longrightarrow$, and - 2013: Characteristics of precipitating convective systems accounting for the summer rainfall of tropical and subtropical South America. J. Hydrometeor., 14, 25-46, https://doi.org/10.1175/JHM-D-12-060.1.
Salzmann, N., C. Huggel, M. Rohrer, W. Silverio, B. G. Mark, P. Burns, and C. Portocarrero, 2013: Glacier changes and climate trends derived from multiple sources in the data scarce Cordillera Vilcanota region, southern Peruvian Andes. Cryosphere, 7, 103-118, https://doi.org/10.5194/tc-7-103-2013.

Schauwecker, S., and Coauthors, 2017: The freezing level in the tropical Andes, Peru: An indicator for present and future glacier extents. J. Geophys. Res. Atmos., 122, 5172-5189, https://doi.org/10.1002/2016JD025943.

Vuille, M., 1999: Atmospheric circulation over the Bolivian Altiplano during dry and wet periods and extreme phases of the Southern Oscillation. Int. J. Climatol., 19, 1579-1600, https://doi.org/10.1002/ (SICI)1097-0088(19991130)19:14<1579::AID-JOC441>3.0.CO;2-N.

Wagnon, P., P. Ribstein, B. Francou, and J. E. Sicart, 2001: Anomalous heat and mass budget of Glaciar Zongo, Bolivia, during the 1997/98 El Niño year. J. Glaciol., 47, 21-28, https:// doi.org/10.3189/172756501781832593.

Waldvogel, A., 1974: The $N_{0}$ jump of raindrop spectra. J. Atmos. Sci., 31, 1067-1078, https://doi.org/10.1175/1520-0469(1974)031<1067: TJORS $>2.0 . \mathrm{CO} ; 2$.

White, A. B., D. J. Gottas, E. T. Strem, F. M. Ralph, and P. J. Neiman, 2002: An automated brightband height detection algorithm for use with Doppler radar spectral moments. J. Atmos. Oceanic Technol., 19, 687-697, https://doi.org/ 10.1175/1520-0426(2002)019<0687:AABHDA > 2.0.CO;2.

Wolter, K., and M. S. Timlin, 1993: Monitoring ENSO in COADS with a seasonally adjusted principal component index. Proc. 17th Climate Diagnostics Workshop, Norman, OK, NOAA/ NMC/CAC/NSSL, 52-57.

Yuter, S. E., D. E. Kingsmill, L. B. Nance, and M. Löffler-Mang, 2006: Observations of precipitation size and fall speed characteristics within coexisting rain and wet snow. J. Appl. Meteor. Climatol., 45, 1450-1464, https://doi.org/10.1175/ JAM2406.1. 